\title{
SEISMIC ZONATION AND DEFAULT SUITES OF GROUND-MOTION RECORDS FOR TIME-HISTORY ANALYSIS IN THE SOUTH ISLAND OF NEW ZEALAND
}

\author{
Christianos A.G. Burlotos ${ }^{1}$, Kevin Q. Walsh ${ }^{2}$, Tatiana Goded ${ }^{3}$, \\ Graeme H. McVerry ${ }^{4}$, Nicholas J. Brooke ${ }^{5}$ \\ and Jason M. Ingham ${ }^{6}$
}

(Submitted September 2020; Reviewed November 2020; Accepted April 2021)

\begin{abstract}
The rise of performance-based earthquake engineering, in combination with the complexity associated with selecting records for time-history analysis, demonstrates an expressed need for localized default suites of ground motion records for structural designers to use in the absence of site-specific studies. In the current research investigation, deaggregations of probabilistic seismic hazard models (National Seismic Hazard Model, Canterbury Seismic Hazard Model, and Kaikōura Seismic Hazard Model) and the location-specific seismological characteristics of expected ground motions were used to define eight seismic hazard zonations and accompanying suite profiles for the South Island of New Zealand to satisfy the requirements of the New Zealand structural design standard NZS1170.5 for response-history analyses. Specific records, including 21 from the recent Kaikōura, Darfield, and Christchurch earthquakes, were then selected from publicly-available databases and presented as default suites for use in time-history analyses in the absence of site-specific studies. This investigation encompasses seismic hazards corresponding to 500-year return periods, site classes $\mathrm{C}$ (shallow soils) and D (deep soils), and buildings with fundamental periods between 0.4 and 2.0 seconds.
\end{abstract}

\section{INTRODUCTION}

In order to accurately simulate the resilience to earthquakes of buildings and infrastructure facilities in a community, engineers and other researchers must model the performance of both building structural and non-structural components [1]. The extent of linear-elastic and nonlinear pseudo-static "pushover" assessment methods are limited due to these methods not encompassing the full spectrum of dynamically-induced demand parameters, nor the capacity performance of both acceleration-sensitive and drift-sensitive components. In order to fully utilize the benefits of rapidly improving performancebased design methodologies [2-5], the modelling of both demands and building components is best accomplished using nonlinear time-history analysis (NLTHA) with appropriately selected ground-motion earthquake records.

To assist engineers utilizing NLTHA in New Zealand, criteria for the selection and scaling of ground-motion records is defined in NZS 1170.5:2016 [6,7], henceforth referred to as "the Standard". However, the process for selecting such records often requires the consultation of seismologists, because it is beyond the capacity of most designers to utilize the probabilistic seismic hazard models used to define the sitespecific hazard spectra and to identify the ground motion sources which contribute to these spectra. Site-specific hazard studies can be cost-prohibitive, especially in early design stages prior to the procurement of construction funding. Thus, the goal of the current study was to recommend a suite of NZS1170compliant ground-motion records for engineers conducting provisional design and assessment of buildings in the South
Island of New Zealand. The current study is a companion to the work presented by Oyarzo-Vera et al. [8] for the North Island of New Zealand. Similar studies have been performed by others elsewhere in the world [9]. However, the current study is differentiated not only by its focus on a different geographic location but also by its use of the 2010 National Seismic Hazard Model (NSHM) [10,11] in place of the 2002 model [12], further updated first in the Canterbury Earthquake Region [13] and Amendment 1 of NZS1170.5 [6] due to the 2010-2011 Canterbury earthquake sequence [14,15], and then by incorporation of the Kaikōura Seismic Hazard Model (described in a later section). As well, this study includes the selection of ground-motion records from the 2010 Darfield and 2011 Christchurch earthquakes and the 2016 Kaikōura earthquake. The suites include 21 different records from these events. It is the intent of the authors that the recommendations of the current study aid in the continuing rebuild of buildings and infrastructure facilities in the South Island of New Zealand.

\section{GENERAL METHODOLOGY AND HIERARCHY OF CONTRIBUTING FACTORS}

The general methodology utilized to select records is presented graphically in Figure 1. Seismic zonation in the current study was generated by identifying geographic regions with similar seismic hazard source content, with a total of eight zones. A suite profile was generated for each geographic zone that consists of the most representative hazard scenarios, wherein each scenario has contributing sources with similar distributions of magnitudes, source-to-site distances, and earthquake types. Records were then selected based on their

${ }^{1}$ Corresponding Author, Graduate Student, Department of Civil and Environmental Engineering and Earth Sciences, University of Notre Dame, Notre Dame, Indiana,USA, cburloto@nd.edu

${ }^{2}$ Director, Resiliency and Sustainability of Engineering Systems \& Assistant Teaching Professor, Department of Civil and Environmental Engineering and Earth Sciences, University of Notre Dame, Notre Dame, and Senior Structural Engineer, Frost Engineering and Consulting, Mishawaka, Indiana, USA

${ }^{3}$ Seismic Hazard Scientist, GNS Science, Lower Hutt (Member)

${ }^{4}$ Retired (Ex Principal Scientist) GNS Science, Lower Hutt (Life Member)

5 Principal, Compusoft Engineering Limited, Auckland (Member)

${ }^{6}$ Professor, Department of Civil and Environmental Engineering, University of Auckland, Auckland (Fellow) 
spectral matching scores (described in a later section) and the following criteria, in descending order of importance: magnitude, tectonic class (i.e., crustal, subduction interface or subduction slab), shortest distance to the fault (RRUP), fault mechanism, site class, geographical location, and $k_{l}$ scaling factor. Additional guidance on selecting and scaling earthquake ground-motions for performing NLTHAs has been published elsewhere [16,17]. Finally, a recommended suite of records was produced for the two most prevalent soil site classes (shallow and deep soils) in each of the eight different seismic hazard zones.

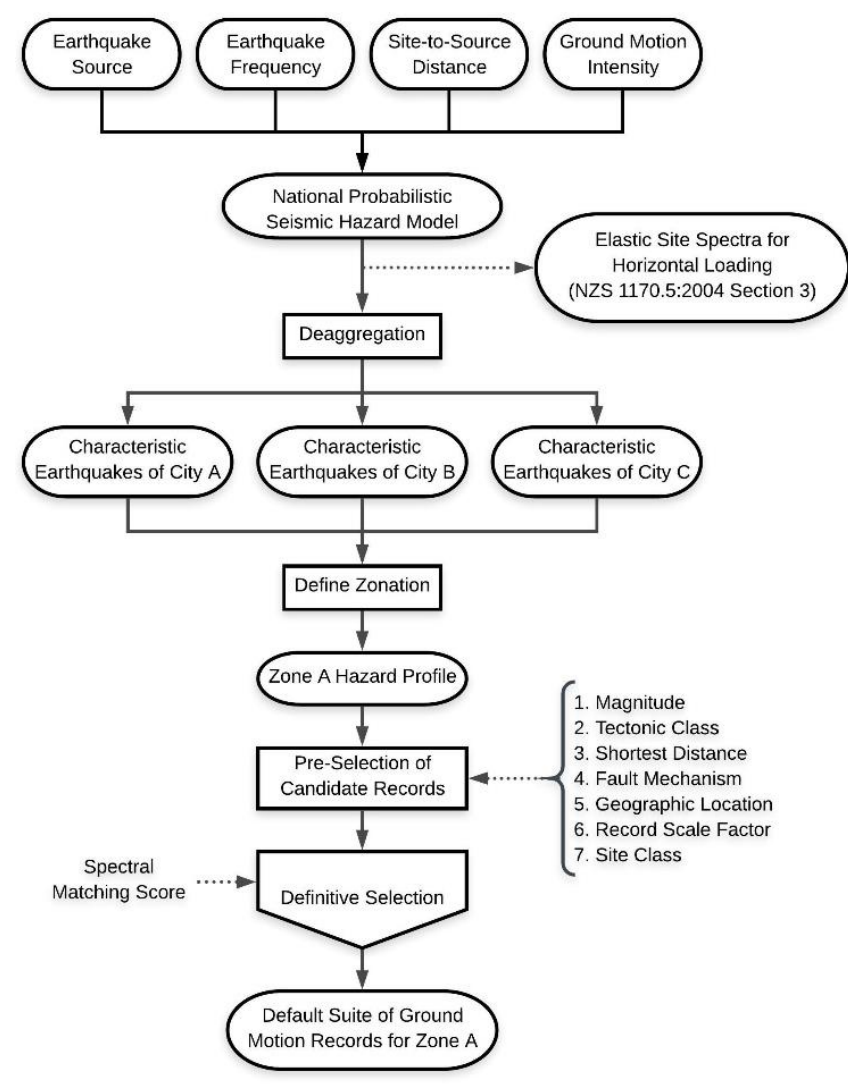

Figure 1: Ground-motion record suite selection methodology.

\section{SEISMICITY OF THE SOUTH ISLAND}

New Zealand is located on the boundary of the Australian and Pacific plates, resulting in a highly active tectonic region. Figure 2 illustrates the seismological characteristics of New Zealand. There are four primary zones of seismic activity in New Zealand [11,12], three of which are applicable to the South Island: 1. The Fiordland subduction zone which lies at the far south-western end of the South Island; 2. The Hikurangi subduction zone in the north-eastern end of the South Island (and also the south-eastern corner of the North Island); and 3. The 1000-km long region connecting these two subduction zones known as the axial tectonic belt consisting of dextral oblique slip faults, including in the South Island the Alpine Fault and other major fault systems branching from it.

To account for the variation in seismic hazard throughout New Zealand, the Standard utilizes a hazard factor Z, defined in the Standard [7] as:

0.5 times the magnitude-weighted...5\% damped response spectrum acceleration for $0.5 \mathrm{~s}$ period for site class $C$ (shallow soil) that has a return period of 500 years. It corresponds to the value in $g$ of the peak ground acceleration (corresponding to
0.0 s period) for site classes A and B (rock) for [ a return period of 500 years]. The range of $Z$ has been limited by a lower bound of 0.13 .

It should be noted that $\mathrm{Z}$ is not defined as the 500 -year rock PGA, but merely that in the Standard these PGA values are set numerically equal to $\mathrm{Z}$, in a similar way to the peak of the 500year Class D spectrum being specified as equal to $3 Z$.

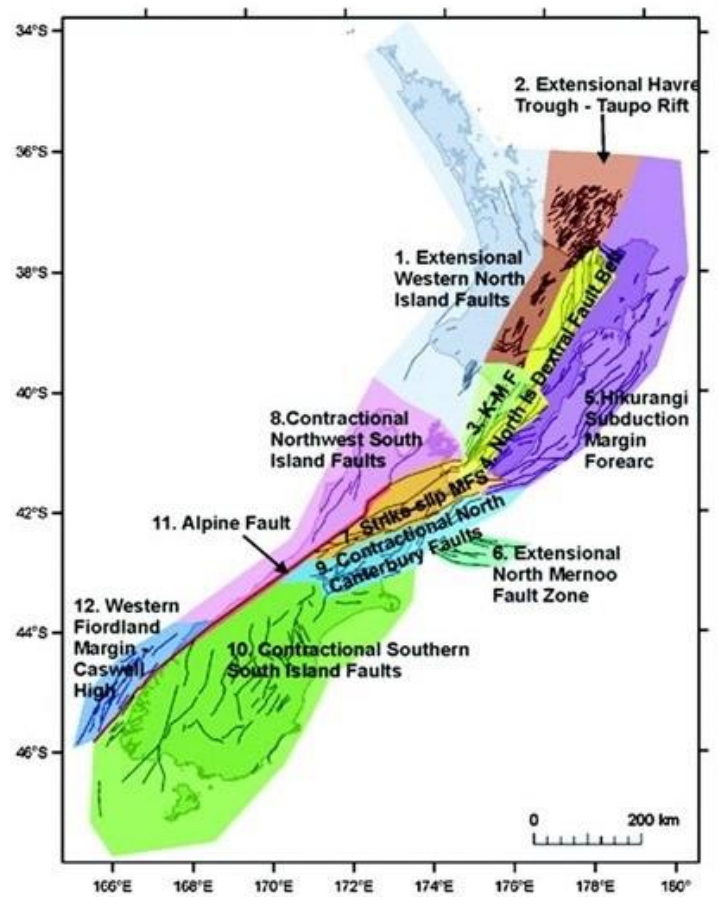

Figure 2: Plate tectonic setting of New Zealand [11].

The Standard presents a map of the hazard factor for the South Island of New Zealand as shown in Figure 3. The hazard factor contours shown in Figure 3 were utilized to define the major boundaries of the eight seismic hazard zones defined in the current study (Figure 4), as discussed in the following sections. The hazard factors are also a necessary component in scaling the ground-motion records to target design spectra [6].

The hazard zones were determined from similarity of the earthquakes (magnitudes, distances, tectonic types, and mechanisms for crustal earthquakes) contributing to the hazard across a zone, as shown by deaggregation analyses of the hazard. The zones determined in this way were then for convenience defined by boundaries given by a combination of contours of the hazard factor $\mathrm{Z}$ or the distance of $20 \mathrm{~km}$ from the closest of eight major South Island faults listed in NZS1170.5 for which it requires the use of near-fault factors. Further discussion of the near-fault factors is given in the section titled Zone South NF.

\section{NATIONAL SEISMIC HAZARD MODEL}

For most of the South Island, the seismicity models used in this study are the fault and distributed seismicity components of the 2010 version of the National Seismic Hazard Model (NSHM) [11], updated from the 2002 NSHM [12]. Separate models, described in the following sections, were used for the Canterbury Earthquake Region and the source zone of the 2016 Kaikoura earthquake, both for the hazard calculations and deaggregations. Although inconsistent with the NSHM, updated models were applied in these regions due to the rapid research development in both areas in response to recent earthquakes. 


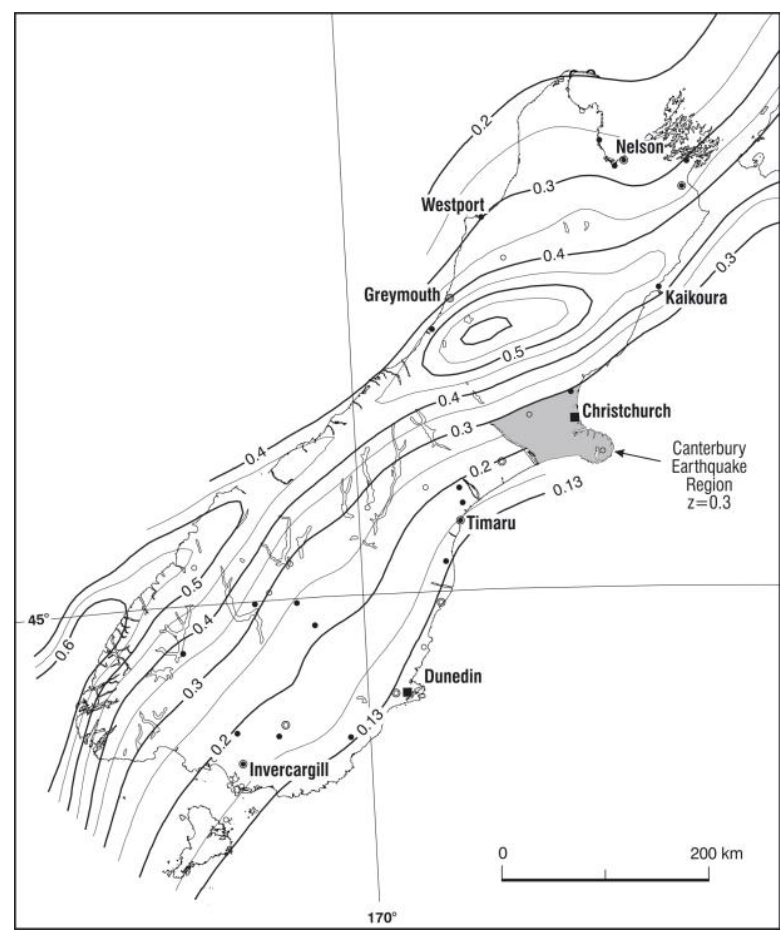

Figure 3: Hazard factor (Z) mapping for the South Island of New Zealand [6].

It should be noted that the records are scaled to match the NZS1170.5 spectra, which is based on the 2002 NSHM model [12]. However, the deaggregations have been carried out using the most recent NSHM, from 2010 [11]. The new model is used to account for the most recent representation of the seismicity in New Zealand (outside the Canterbury Earthquake Region and the source zone of the 2016 Kaikōura earthquake), rather than the old version from 2002. Projects for which special hazard studies are performed usually use the latest models both for defining the spectra and performing the deaggregations, so this represents a position part way between using the NZS1170.5 hazard representation in its entirety and performing a complete update of the NZS1170.5 results.

The hazard analysis has been carried out using McVerry et al. [18] ground motion prediction equations (GMPE), as the equations have been used in the NSHM [11,12] and to form the basis of the hazard prescribed in the New Zealand structural design standard [6].

The hazard calculations and deaggregations have been performed using "magnitude-weighting" for periods up to and including 0.5 seconds, to be consistent with the procedures used to derive the NZS1170.5 hazard factors and spectral shapes. Magnitude-weighting reduces the influence of earthquakes less than moment magnitude $\mathrm{M}_{\mathrm{w}} 7.5$, to reflect magnitudedependent duration effects which affect the damage potential of motions for a given peak response. It involves scaling the acceleration values estimated for events of magnitude $\mathrm{M}_{\mathrm{w}}$ less than 7.5 by the factor $\left(\mathrm{M}_{\mathrm{w}} / 7.5\right)^{1.285}$, a factor first used in liquefaction analyses (e.g., Seed \& Idriss, 1982 [47]). The magnitude-weighting is applied in the course of the hazard calculations by modifying the median values of the accelerations for given values of magnitude, distance, etc. to their magnitude-weighted values when calculating the probabilities of exceedance of each acceleration value by a modelled earthquake event. This is the same procedure that was used in deriving the NZS1170.5 hazard spectra.

In general, epistemic uncertainties in the GMPEs have not been considered in this project. The reason for this is to be consistent with the Standard [6], which does not mention the consideration of uncertainties in GMPEs. In addition, epistemic uncertainties were not considered in the default records for the North Island [8], thus this methodology is consistent with that publication. An exception was the Canterbury Earthquake Region, where a combination [14] of variants of the McVerry et al. [18] and Bradley GMPEs [19] were used.

\section{CANTERBURY AND KAIKŌURA SEISMIC HAZARD MODELS}

For the Canterbury Earthquake Region, as defined by the Standard [6,7] and shown as Zone South C in Figure 4, the seismic hazard model utilized is the Canterbury Seismic Hazard Model (CSHM) [14], developed to account for the ongoing sequence of earthquakes in Canterbury following the Darfield 2010 and Christchurch 2011 earthquakes. The CSHM was used for this region because it was the basis for the increased design spectra in the 2016 revision of the NZS1170.5 standard [6, 7]. The two locations chosen for deaggregation in the Canterbury Earthquake Region (see Figure 4) have multiple GMPEs as used in the CSHM [14].

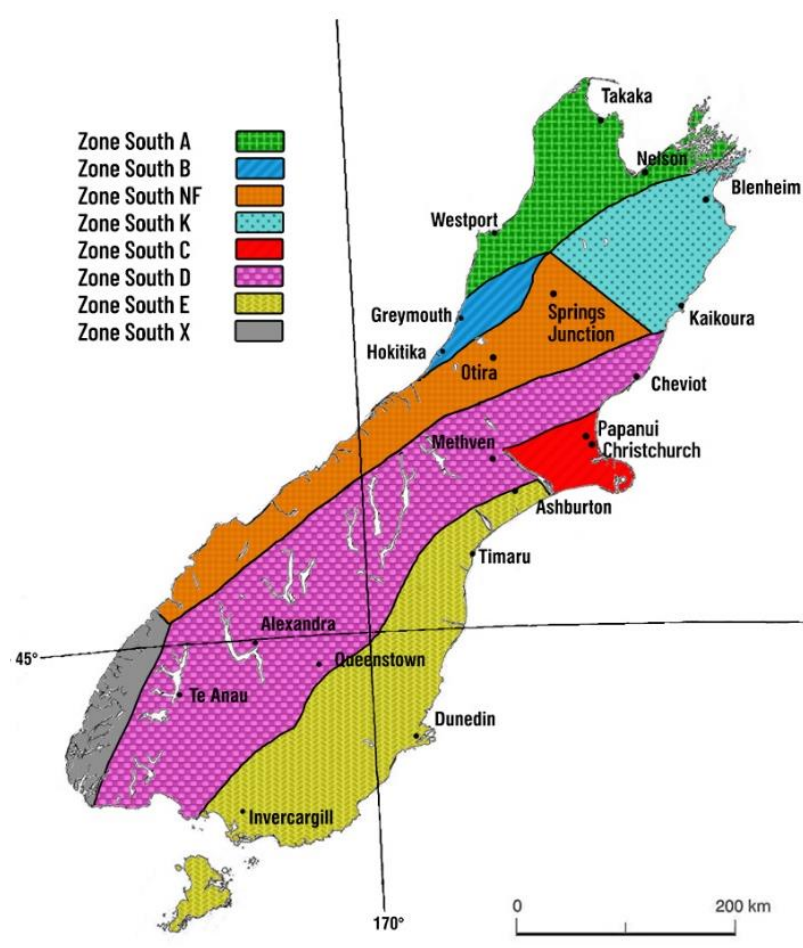

Figure 4: Seismic hazard zonation for the South Island of New Zealand proposed for the selection of suites of groundmotion records.

The hazard analysis in Kaikōura and Blenheim (South Zone K; see Figure 4) have been carried out using the Kaikōura Seismic Hazard Model (KSHM) [20,21] due to additional heightened levels of activity as a result of the 2016 Kaikoura earthquake. South Zone K was determined by using the hazard results of KSHM to identify the area in which the hazard deaggregations were changed substantially from those of the 2010 NSHM. The KSHM source model uses new data on fault configurations and parameters [22], as well as earthquake clustering (i.e., distributed seismicity) models. The KSHM allows multi-fault ruptures, including one option which encompasses all the major faults that ruptured the ground surface in the Kaikoura Earthquake. The KSHM fault source model considerably modifies the 541 fault sources of the 2010 NSHM, with the addition of 29 new fault sources [20-22].

Similarly, the KSHM addresses uncertainty regarding Hikurangi subduction zone sources through an adjustment to the 2010 NSHM for these sources. Other advances incorporated 
in the KSHM include using a suite of New Zealand and international ground motion prediction equations (GMPEs) in a logic tree format so as to incorporate uncertainty, consistent with international best practice and the New Zealand Dam Safety Guidelines [23], as now being used routinely by GNS Science in seismic hazard modelling. The GMPEs in the KSHM and the weights given to them are based largely on the analysis of GMPE performance [24] using New Zealand strong motion data [25]. State of the art time-varying earthquake modelling is also incorporated. The clustering model includes short- and medium-term time-varying components as well as a long-term time-invariant component.

\section{SEISMIC ZONATION AND EXPECTED GROUND MOTION CHARACTERISTICS}

The 2010 NSHM was run to produce deaggregation analyses for 16 locations in New Zealand's South Island. In addition, deaggregations for two locations in Christchurch were obtained using the CSHM [14] with combinations of variants of the McVerry et. al [18] and Bradley [19] GMPEs. Likewise, deaggregations for two locations in the source zone of the 2016 Kaikōura Earthquake were obtained using the KSHM [20,21]. The deaggregation plots for the locations identified in Figure 4 are shown in Figure A1, wherein the percent contributions toward the aggregated hazard exceedance rate for the hazard factor $\mathrm{Z}$ corresponding to the 500-year return design basis earthquake are plotted in terms of the moment magnitude (Mw), and source-to-site distance $(\mathrm{km})$ of the contributing sources. These locations represent the major urban centres (the few cities and many towns) of the South Island and hence the regions where the largest numbers of existing or planned buildings reside. A brief discussion follows regarding each zone (Figure 4 ) and its source (Figure 2) and hazard characteristics as shown by Figures 3 and A1. For more detailed information on the seismic characteristics of each zone, please refer to other literature [10-12,14,15]. In particular, the exact locations of the specific faults identified below can be found in Stirling et al. [11].

The seismic hazard zonation presented in this paper (Figure 4) for selecting suites of ground-motion records is based on the similarity of seismological characteristics (the tectonic types, fault mechanisms, and magnitudes of the dominant sources) within the zones. It was expected that these similarities of the sources within a zone would lead to similar hazard deaggregations within a zone. The validity of this assumption is commented on further under the discussion of each of the zones.

The deaggregation plots for each of the selected locations in the South Island are shown in Figure A1 based on spectral periods of 0.5 seconds. Deaggregation plots were also processed for spectral periods of 1.0, 1.5 and 2.0 seconds (not shown herein). Recommended hazard profiles for each zone are presented in Table 1 based on the hazard deaggregations for the range of aforementioned spectral periods. The applicability of the ground-motion records proposed in the current study is for buildings with fundamental periods between 0.4 and 2.0 seconds, due to the restrictions imposed by the Standard on scaling records at lower periods [6].

\section{Zone South A}

Zone South A corresponds to the north-western area of the South Island, where the hazard factor $(\mathrm{Z})$ per the Standard is less than 0.35 (see Figure 3), and the zone has an eastern limit defined by locations in the source region for the 2016 Kaikōura Earthquake (Zone K). Zone South A has a moderate seismic hazard primarily governed by "distributed" seismicity, although the distributed seismicity makes little contribution to the hazard for Nelson. The northern part of this zone is influenced by subduction interface events from the Hikurangi subduction zone, and the southern part of this zone is strongly influenced by strike-slip events from the Alpine fault (see Figure 2).

\section{Zone South B}

Zone South B is a relatively small zone situated on the west coast of the South Island and has a northern limit defined by the 0.35 hazard factor contour (see Figure 3 ) and an eastern limit defined by locations where ground-motion records must include near-fault effects per the Standard (i.e., Zone NF). This zone has a high seismic hazard which is strongly influenced by large strike-slip events originating from the Alpine fault. Although lying outside Zone South B, the Kelly fault contributes $21 \%$ to the disaggregated seismicity plotted for Hokitika in this zone (see Figure A1e). The deaggregations for the two locations (Greymouth and Hokitika) selected in this zone are similar (Figures A1d and A1e).

\section{Zone South NF}

Zone South NF is located in the central western side of the South Island and has a high seismic hazard with hazard factors ranging from 0.40 to 0.60 . It consists of the South Island part of the region defined by the Standard as requiring the use of nearfault factors minus that part of the near-fault region lying in Zone South K, the source zone of the 2016 Kaikoura earthquake, as discussed in the next section. Figure 3.5 and Table 3.6 of the Standard identify the faults requiring the use of near-fault factors, which consist of the most active major strikeslip faults in New Zealand ( $\mathrm{M}>7.0$ and slip rate $>5 \mathrm{~mm} /$ year), and defines the extent of their near-fault influence as a region where the distance to these faults is less than $20 \mathrm{~km} \mathrm{[6].} \mathrm{As} \mathrm{a}$ result, the western and eastern parts of the Zone South NF boundaries are defined using this provision in the Standard to represent the influence of near-fault effects from these faults while the north-eastern extent of Zone South NF is truncated by Zone South K (Figure 4). A near-fault factor is provided in the Standard to modify the spectrum dependent on spectral period and distance from the closest of multiple major fault strike-slip and reverse faults. The two locations processed in this zone, Otira and Springs Junction, correspond to critical points along main roads on the South Island. 50\% of the disaggregated seismicity plotted for Springs Junction (see Figure A1h) originates from the Alpine (Kaniere-Tophouse) fault, whereas the Kelly fault contributes $58 \%$ of the disaggregated seismicity for Otira (see Figure A1i). However, the overall characteristics of the deaggregations are similar for these two locations.

\section{Zone South K}

Zone South $\mathrm{K}$ is located on the northeast edge of the South Island and corresponds to the source region of the 2016 Kaikōura Earthquake. The region was determined using hazard results $[20,21]$ to identify the area in which the hazard deaggregations were changed substantially from those of the 2010 NSHM. This zone has a high seismic hazard, and the deaggregations for locations within it are generally similar in that they are strongly influenced by large strike-slip events originating from the major faults of the axial tectonic belt (Hope-Conway fault and others in region 7 of Figure 2) and by events on the Hikurangi subduction interface.

\section{Zone South C}

Zone South C corresponds to the Canterbury Earthquake Region, encompassing Christchurch City, the Selwyn District, and the Waimakariri District in which the Z-factor in the Standard as published in 2004 [26] is less than 0.3 (Figure 2). Following the Christchurch earthquake of 2011, the Z-factor for the Canterbury Earthquake Region was increased to 0.3 in May $2011[6,13]$, reflecting the enhanced hazard in this region from 


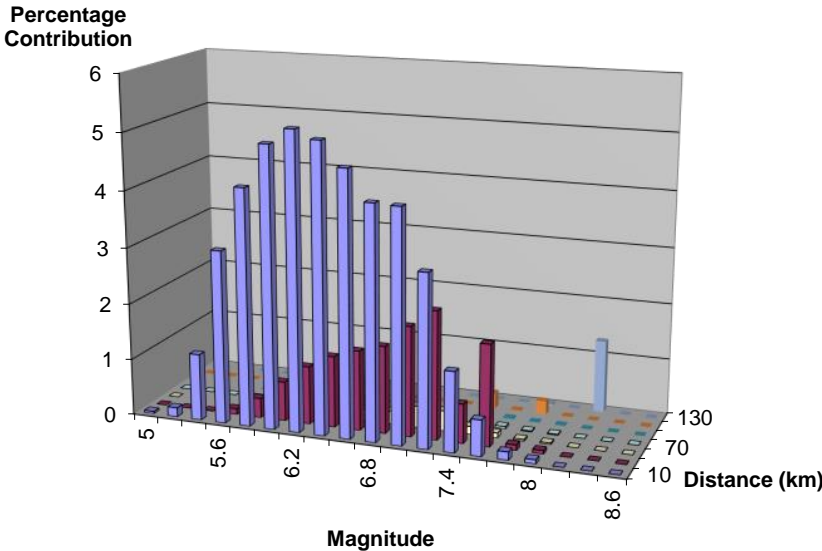

(a) Zone South C: Papanui

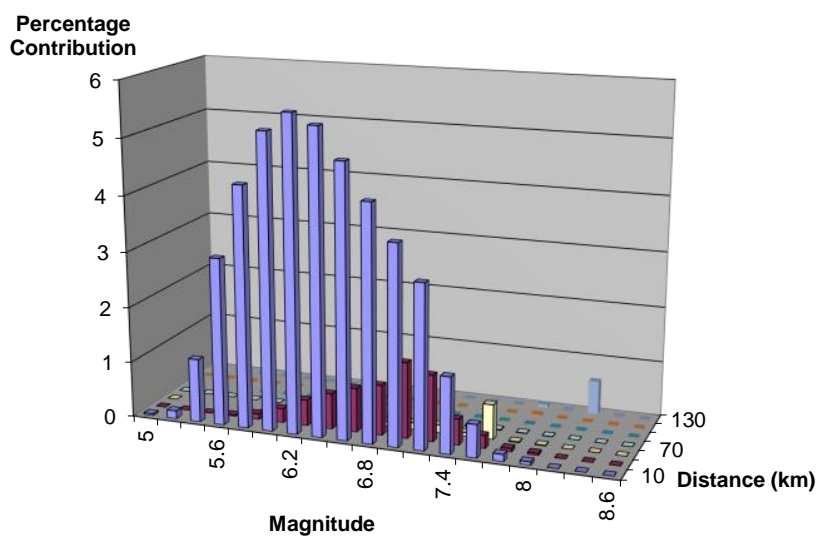

(b) Zone South C: Christchurch CBD

Figure 5: Deaggregation plots for 500-year return period at 0.5 seconds spectral period for the Canterbury Earthquake Region (soil site class D conditions).

aftershocks and the ongoing earthquake sequence that may persist for 50 years or more [14]. It includes the city of Christchurch and its suburbs. Overall, deaggregations (see Figure 5) are sufficiently similar to allow a single suite of records within the same zone. Note that in Figure 5 and all following deaggregation plots, colour is used to differentiate distances.

\section{Zone South D}

Zone South D occupies much of the south-central part of the South Island and is defined on the eastern side by the 0.2 hazard factor contour, the southern and western boundaries of the Canterbury Earthquake Region, and the east coast north of that (see Figure 3). The western side is defined by the locations where ground-motion records must include near-fault effects per the Standard (i.e., Zone NF) and the Fiordland region of South Zone X. Zone South D zone has a moderate to high seismic hazard with hazard factors ranging from 0.20 to 0.55 (see Figure 3). This zone is primarily influenced by strike-slip and reverse faults originating from the Alpine fault zone. However, given the large size of this zone and the remoteness of some of it from the Alpine Fault, the deaggregations at different locations within this zone (Figures $\mathrm{A} 1 \mathrm{j}$ to $\mathrm{A} 1 \mathrm{n}$ ) show greater variation than those for the other zones. For example, $25 \%$ of the aggregated seismic contribution for Cheviot is due to the strike-slip Hope-Conway fault (see Figure A1j), while $5 \%$ of the aggregated seismicity of Te Anau is influenced by the contribution of the Fiordland subduction interface (see Figure A1n) in the south-western corner of the South Island (see Figure 2).

\section{Zone South E}

Zone South E corresponds to the large south-eastern area of the South Island, including Stewart Island, where the hazard factor is less than or equal to 0.20 (see Figure 3). Distributed seismicity and reverse faults represent much of the contributions toward aggregated seismicity in the region. However, again there is wide variation between the deaggregations for the various locations selected in this zone. The Alpine fault contributes approximately $20-40 \%$ toward the aggregated seismicity of cities close to the western border of the region (e.g., Ashburton, Timaru, and Invercargill; see Figures A1o - A1q). Invercargill is subject to far-distance sources (see Figure A1q), including a 5\% contribution from subduction interface events at magnitudes $7.7-8.1$ and $140-$ $200 \mathrm{~km}$ distance that doesn't appear in the other major cities in this zone. For Dunedin, $55-75 \%$ of the contributions are due to distributed seismicity events of magnitude 5.0 to 7.5 with distances less than $80 \mathrm{~km}$ (see Figure A1r). Reverse-faulting earthquakes with magnitudes between 7.3 to 7.5 at distances of 0 to $20 \mathrm{~km}$ contribute approximately $14 \%$ toward the aggregated seismicity of Dunedin, with the Akatore fault being the main contributor. A narrow coastal slither of Zone South E, south of Oamaru, is governed by the minimum hazard factor $\mathrm{Z}$ value of 0.13 allowed by NZS 1170 .

\section{Zone South $\mathbf{X}$}

Zone South X corresponds to the south-western area of the South Island and is a region of high seismic hazard, with hazard factors ranging from 0.40 to 0.60 (see Figure 3). This zone is significantly influenced by subduction earthquakes resulting from the Fiordland subduction interface (see Figure 2). This zone is largely unpopulated. Since a suitable town for deaggregation analysis could not be chosen, no suite profile or recommended records were derived for Zone South X.

\section{SELECTION OF THE DEFAULT SUITE OF RECORDS FOR EACH ZONE}

At present, the Standard [6] and Eurocode 8 [27] require that not less than three records be considered for NLTHA. In contrast, the American Society of Civil Engineers recently increased their recommended number from seven to eleven records $[28,29]$. Because the appropriate number of records needed is still a developing topic of research [30], this study will adhere to the typical practice in structural design $[16,17,27,28]$ and recommend suites of seven ground-motion records for NLTHA.

Hazard scenario groupings were identified for each zone based on the contributing magnitude-distance combinations identified in Figure A1, combined with source types from deaggregation printouts and Figure 2. Each hazard scenario was then assigned a number of ground-motion records proportional to its percentage contribution toward the aggregated seismicity, totalling seven for each zone. In some cases, contributors of different source mechanisms to the same magnitude-distance set were identified. In such cases, an extra record was recommended to represent all applicable mechanisms, such as in the case of subduction interface contributions in zones South A and South D. The suite profiles, consisting of the significant characteristic earthquake hazard scenarios contributing to the 500-year aggregated seismic hazard for each zone, are shown in Table 1 and are valid for buildings with fundamental periods of between 0.4 and 2.0 seconds in all site classes. Note that, at locations near the major faults listed in the Standard, the Standard requires that one third of the recommended records in each suite shall have a strong forward-directivity component [6]; thus for zones South NF and South K, two records with a 
Table 1: Recommended suite profiles for each seismic zone.

\begin{tabular}{|c|c|c|c|c|c|}
\hline Zone & $\begin{array}{l}\text { Hazard } \\
\text { Scenario }\end{array}$ & Magnitude & $\begin{array}{l}\text { Distance } \\
(\mathrm{km})\end{array}$ & Tectonic Type/Fault Mechanism & $\begin{array}{c}\text { Recommended } \\
\text { No. of } \\
\text { Records } \\
\end{array}$ \\
\hline \multirow{4}{*}{ South A } & A1 & $5.0-7.1$ & $0-60$ & Reverse faulting records & 4 \\
\hline & A2 & 7.5-7.9 & $60-120$ & Strike-slip faulting records & 2 \\
\hline & A3 & $8.1-8.5$ & $80-160$ & Subduction interface records & 1 \\
\hline & A4 & $8.1-8.3$ & $120-140$ & Strike-slip faulting records & 1 \\
\hline \multirow{3}{*}{ South B } & B1 & $6.9-7.5$ & $20-60$ & Strike-slip faulting records & 3 \\
\hline & $\mathrm{B} 2$ & 7.7-7.9 & $20-40$ & Strike-slip faulting records & 1 \\
\hline & $\mathrm{B} 3$ & $8.1-8.3$ & $20-60$ & Strike-slip faulting records & 4 \\
\hline \multirow{3}{*}{ South NF } & NF1 & $5.5-7.1$ & $0-40$ & Strike-slip faulting records & 1 \\
\hline & NF2 & 7.1-7.9 & $0-20$ & $\begin{array}{l}\text { Strike-slip or strike-slip with reverse components faulting } \\
\text { records. } 2 \text { with forward directivity }\end{array}$ & 5 \\
\hline & NF3 & 7.9-8.3 & $20-40$ & Strike-slip faulting records & 1 \\
\hline \multirow{3}{*}{ South K } & $\mathrm{K} 1$ & $5.5-6.9$ & $0-20$ & Strike-slip faulting records & 2 \\
\hline & $\mathrm{K} 2$ & $6.9-7.9$ & $0-20$ & Strike-slip faulting records. 2 with forward directivity & 4 \\
\hline & K3 & 7.9-8.5 & $0-40$ & Subduction interface records & 1 \\
\hline \multirow{4}{*}{ South C } & $\mathrm{C} 1$ & $5.0-5.9$ & $0-20$ & Reverse faulting records & 1 \\
\hline & $\mathrm{C} 2$ & $6.0-6.9$ & $0-20$ & Reverse faulting records & 3 \\
\hline & $\mathrm{C} 3$ & 7.0-7.7 & $0-40$ & Reverse faulting records & 2 \\
\hline & $\mathrm{C} 4$ & $8.1-8.3$ & $120-140$ & Strike-slip faulting records & 1 \\
\hline \multirow{4}{*}{ South D } & D1 & $5.0-7.5$ & $0-60$ & Reverse faulting records & 4 \\
\hline & D2 & $7.5-8.1$ & $20-80$ & Strike-slip faulting records & 1 \\
\hline & D3 & $7.5-8.1$ & $20-80$ & Subduction interface records & 1 \\
\hline & D4 & $8.1-8.3$ & $60-140$ & Strike-slip faulting records & 2 \\
\hline \multirow{3}{*}{ South E } & E1 & $5.0-7.1$ & $0-80$ & Reverse faulting records & 3 \\
\hline & E2 & 7.1-7.9 & $40-100$ & Reverse faulting records & 2 \\
\hline & E3 & 7.7-8.3 & $100-240$ & Strike-slip faulting records & 2 \\
\hline
\end{tabular}

strong forward-directivity component were included for both soil site class suites.

The selection of specific records for each suite closely followed the methodology of Oyarzo-Vera et al. [8] but with some amendments. This process is outlined as follows:

\section{Pre-Selection of Candidate Records}

Using four publicly available ground-motion records databases [31-34], records were first pre-selected as candidates for each zone based upon a hierarchical combination of record characteristics. The hierarchy of record pre-selection criteria used are in descending order of importance as follows: magnitude, tectonic class, shortest distance, fault mechanism, site class, geographic location, and $k_{l}$ scaling factor. Adhering strictly to all selection criteria was not always achievable due to the limitations of records in the four databases, particularly in the case of high-magnitude strike-slip events. While enough total records were considered such that these pre-selection criteria were able to be met in the vast majority of cases, it is important to stress that the fit of the spectral shape to the NZS1170 target spectra, i.e., the definitive selection described in the next section, is significantly more important than most of the above parameters.

The list of all 213 ground-motion records that were preselected for this study can be found in Table A1.

Of the four databases [31-34] used for selection of groundmotion records, only the New Zealand Strong-Motion Database [34] provides the NZS1170.5 site class, which is based on site period $\mathrm{T}_{\text {site, }}$, while the others provide $\mathrm{V}_{\mathrm{S} 30}$ (the travel-time averaged shear-wave velocity from the surface to $30 \mathrm{~m}$ depth). There is not a one-to-one correspondence between $\mathrm{T}_{\text {site }}$ and $\mathrm{V}_{\mathrm{S} 30}$. In particular, the NZS1170.5 [6] Classes C and D do not correspond to the ASCE [29] Classes $\mathrm{C}$ and D. The ASCE $\mathrm{V}_{\mathrm{S} 30}$ ranges are $360 \mathrm{~m} / \mathrm{s}<\mathrm{V}_{\mathrm{S} 30}$ $<760 \mathrm{~m} / \mathrm{s}$ for Class C Shallow Soil and $180 \mathrm{~m} / \mathrm{s}<\mathrm{V}_{\mathrm{S} 30}<$ $360 \mathrm{~m} / \mathrm{s}$ for Class D Deep Soil. NZS1170.5 Class C Shallow Soil is characterised by a site period of less than 0.6 seconds (excluding rock sites), with NZS1170.5 Class D Deep or Soft Soil having a site period greater than 0.6 seconds, but excluding Class E Very Soft Soil sites, as defined in the Standard [6]. As an example, deep stiff glacial deposits of up to several hundred metres depth above rock occur commonly in New Zealand. These typically have $\mathrm{V}_{\mathrm{S} 30}$ in the ASCE class C range of 360 to $760 \mathrm{~m} / \mathrm{s}$, but their depth places them in NZS1170.5 Class D Deep or Soft Soil sites. The Class D minimum site period of 0.6 seconds is achieved with a rock boundary at $54 \mathrm{~m}$ depth where the overlying material has an average $V_{S}$ of $360 \mathrm{~m} / \mathrm{s}$, and with a rock boundary at $114 \mathrm{~m}$ depth for overlying material with an average $V_{S}$ of $760 \mathrm{~m} / \mathrm{s}$. In the development of the NZS1170.5 site classes, it was found that deep stiff soil sites "would be assigned to a classification associated with spectra rich in long-period content in the New Zealand classification, but to a class characterised by short-period spectra in the $\mathrm{V}_{30}$ approach" [18].

The site-period basis for the NZS1170.5 assignment of site class means that knowledge of $\mathrm{V}_{\mathrm{s} 30}$ alone is not sufficient to determine the site class. Fortunately, it appears that spectral shape is a more important parameter than site class per se, so the determination of whether a record is produced by a site with an NZS1170.5 classification of C or D is relatively unimportant provided it matches the target spectral shape well.

\section{Definitive Selection of Records for Each Zone}

The definitive selection of pre-selected records was based upon the requirements in the Standard for a record to have a reasonable fit and possess a sufficiently similar amplitude to the target spectrum [6]. These requirements were only considered for the spectral period range of interest, between 0.4 and 2.0 seconds. As the Standard does not permit the modification of records' frequency content for NLTHA, the engineers applying these records only need to scale them appropriately as defined in the Standard [6], subject to the constraints on the measure-of-fit parameter $\mathrm{D}_{1}$, as discussed in the following paragraphs. 
The Standard defines what qualifies as a reasonable fit to the NZS1170 target spectra, founded on a criterion related to the root mean square difference between the logarithms of the scaled primary component and the target spectra over the period range of interest ( $0.4 T$ to $1.3 T$ ), as follows:

$D_{1}=\sqrt{\frac{1}{(1.3-0.4) \cdot T} \cdot \int_{0.4 T}^{1.3 T}\left[\log \left(\frac{k_{1} \cdot \text { Record Spectrum }}{\text { Target. Spectrum }}\right)\right]^{2} d \tau} \leq \log (1.5)$

where the principal component is determined according to the Standard [6];

$T=$ fundamental period of the structure; and

$k_{l}=$ record scale factor that minimizes Equation 1.

A normalized spectral matching score (SMS) ranging from 0 to 1 was assigned to each record based on its principal $D_{l}$ value. The SMS corresponds to the score for that record with respect to the maximum possible score of 20 summed across 5 matching periods. Scores are calculated for periods of $0.4 \mathrm{~s}$, $0.5 \mathrm{~s}, 1.0 \mathrm{~s}, 1.5 \mathrm{~s}$ and $2.0 \mathrm{~s}$, with a maximum score of 4 for each period. The goodness-of-fit of each acceleration record to the target spectrum was evaluated using a scoring system developed by GNS Science, as detailed in Oyarzo-Vera et al. [8]. The Z-factor and near-fault factor were set to a default 1.0 for the calculation of the SMS. Records are considered acceptable if SMS is 0.55 , and are considered excellent matches if SMS $\geq 0.83$. The mean of SMS values in each suite range from 0.77 to 0.85 , indicating that the spectral shapes of the selected records have a very strong fit with the target spectra.

In general, the pre-selected records with the highest SMS (i.e. best-fit to the target spectra) were selected for the default record suites. Exceptions made to the above listed prioritization criteria and numerical procedure were as follows:

1. The El Centro Array \#9 record from the 1940 Imperial Valley-02 event (often recognized as El Centro 1940) was frequently included due to its widespread use in the New Zealand engineering community because of its nearly constant spectral velocity over a broad period range and close spectral match to the shapes of the NZS1170.5 spectra for site classes C and D. It is important to note that the 1940 El Centro earthquake ruptured away from the recording station, and thus the record should not be used to represent forward-directivity ground motions. However, the El Centro record was retained because of its good spectral match to the NZS1170.5 spectral shapes.

2. Where the hazard scenario was accommodated, records from relatively recent domestic earthquakes - 2010 Darfield, 2011 Christchurch, and 2016 Kaikōura - were prioritized for use over international records;

3. No more than one record was chosen from a specific event, nor was more than one event chosen from a specific station, within the same records suite. A single exception was made for the site class D suite for zone South B, in which two Kaikōura records were used due to a sparsity of highmagnitude strike-slip events available from other events. Thus, an additional record was added to this suite to ensure that seven unique events were represented in each suite. The restriction of only a single record per event was imposed because of concerns about possible within-event correlations carried over from old practice when the relative amounts of site-to-site and event-to-event variability was unknown. Modern ground motion models show that the variability between sites in ground motions for a given event greatly exceeds the event-to-event variability;

4. When considering records from stations outside of New Zealand, geographic diversity was prioritized. As with the restriction of only a single record per event, this selfimposed constraint is difficult to justify;

5. When considering domestic records, priority was given to records from stations physically located within the geographic zone being considered. Records from stations within the specific zone are bolded in Table 2; and

6. Due to a sparsity of high-magnitude strike-slip event records in the four considered databases, the TAPS Pump Station \#11 record from the 2002 Denali, Alaska event was used in the majority of the suites. This record was selected because of its superior fit with both deep and shallow soil target. spectra, even if the magnitude (7.9) is lower than the one required for the set. (8.1-8.3, e.g., hazard scenario A4 in Table 2). Reviewer Paul Somerville has noted that "the locally supersonic rupture velocity near this site diminished the amplitude of the forward rupture directivity pulse that would ordinarily be expected at this site." This record has not been used as a forward-directivity record in this study.

The specific recommended suites of records for each zone for site classes C and D (as defined in the Standard) are presented in Table 2. These two site classes, which constitute the majority for South Island building projects, were also selected to address with priority soil classes which generally more greatly amplify shaking effects on buildings and to remain consistent with Oyarzo-Vera et al. [8]. Justification for the soil site classes assumed for the stations identified in the records suites was determined based on external literature [8,35-39]. $V_{S 30}$ values for each of the stations considered in the current study were also sourced in external literature [24,32,40,41]. It is important to note that $V_{S 30}$ alone is not necessarily indicative of site class; however, the consideration and prioritization of a record's SMS (i.e. definitive selection) ensures that the records selected have a similar shape to the target spectra. The SMS for each individual record, as well as the average spectral matching score for each suite, are also included in Table 2.

Finally, the $k_{l} / R Z$ ratio - the record scale factor (determined by scaling records to NZS 1170 spectra) at a natural period of $T=0.5$ seconds normalized by the hazard factor $(Z)$ and the return period factor $(R)$ - is listed in Table 2 for each record chosen. $R$ was set to a default of 1.0 for these calculations, while $Z$ was set to the maximum hazard factor applicable to each zone (noted in Table 2). The return period factor accounts for the severity of the design event and is prescribed by the Standard [6]. $\mathrm{R}=1.0$ for shaking intensity with an average return period of 500 years. Note that these normalized record scale factors were used for record selection based on a particular fundamental period ( $T=0.5$ seconds) and are only applicable to this period. Different scale factors would generally need to be calculated where NLTHA was to be undertaken for a building with a natural period other than $\mathrm{T}=0.5$ seconds. It is also important to note that at natural periods less than 1.5 seconds, near-fault factors do not affect the $k_{l} / R Z$ ratio.

The Standard requires that the record scale factor, $k_{l}$, be between 0.33 and 3.0. It is recommended that this limitation need not be adhered to when applying the records from this study, particularly in the case of high-magnitude records with large source-to-site distances. Several studies [42-44] have shown that the consistency of the estimated nonlinear structural responses is much more dependent on the spectral shape of the input records than on the degree of scaling required to achieve the target input amplitude. Morris et al. [30] also comments on the need for $k_{I}$ to exceed 3 for high ground-motion intensities or subduction-interface records. 
Table 2: Default record suites (Bold corresponds to New Zealand records recorded in the same geographic area of the zone).

\begin{tabular}{|c|c|c|c|c|c|c|c|c|c|c|c|c|c|}
\hline \multicolumn{2}{|c|}{$\begin{array}{l}\text { Zone: } \\
\text { South A }\end{array}$} & \multicolumn{2}{|c|}{ Max Z: 0.35} & \multicolumn{5}{|c|}{ C - Suite SMS: 0.83} & \multicolumn{5}{|c|}{ D - Suite SMS: 0.83} \\
\hline SC & HS & Station & Event & Country & Date & $\mathbf{M}$ & D & FM & $\mathbf{V}_{\mathrm{S} 30}$ & SMS & $k_{1} / \mathbf{R Z}$ & VS & SCS \\
\hline \multirow{8}{*}{$\mathrm{C}$} & \multirow{4}{*}{$\mathrm{A} 1$} & El Centro Array \#9 & Imperial Valley-02 & USA & 19-May-40 & 7.0 & 6 & SS & 213 & 0.80 & 3.40 & [32] & {$[8]$} \\
\hline & & $\begin{array}{l}\text { Bear Valley \#5, Callens } \\
\text { Ranch }\end{array}$ & Loma Prieta & USA & 18-Oct-89 & 6.9 & 53 & RO & 391 & 0.95 & 14.26 & {$[32]$} & [29] \\
\hline & & LPCC & Darfield, New Zealand & $\mathrm{NZ}$ & 6-Sep-10 & 7.1 & 24 & SS & 760 & 0.75 & 4.92 & [25] & {$[29,36]$} \\
\hline & & TCU122 & Chi-Chi, Taiwan-03 & Taiwan & 20-Sep-99 & 6.2 & 19 & $\mathrm{R}$ & 475 & 0.90 & 5.40 & [32] & [29] \\
\hline & \multirow{2}{*}{ A2 } & Bursa Sivil & Kocaeli & Turkey & 17-Aug-99 & 7.5 & 66 & SS & 613 & 0.60 & 19.00 & [32] & {$[29,35]$} \\
\hline & & RDCS & Kaikōura & $\mathrm{NZ}$ & 14-Nov-16 & 7.8 & 97 & $\mathrm{O}$ & 270 & 0.90 & 18.45 & [25] & [39] \\
\hline & $\mathrm{A} 3$ & Talca & Valparaiso & Chile & 3-Mar-85 & 7.8 & 100 & SDI & 598 & 0.80 & 5.93 & [41] & [29] \\
\hline & $\mathrm{A} 4$ & TAPS Pump Station \#11 & Denali, Alaska & USA & 3-Nov-02 & 7.9 & 126 & SS & 376 & 0.95 & 17.55 & {$[32]$} & [29] \\
\hline \multirow{9}{*}{$\mathrm{D}$} & \multirow{4}{*}{ A1 } & El Centro Array \#9 & Imperial Valley-02 & USA & 19-Мау-40 & 7.0 & 6 & SS & 213 & 0.90 & 4.38 & [32] & [29] \\
\hline & & LB - Rancho Los Cerritos & Northridge-01 & USA & 17-Jan-94 & 6.7 & 52 & $\mathrm{R}$ & 303 & 0.85 & 17.24 & [32] & [29] \\
\hline & & MAYC & Darfield, New Zealand & $\mathrm{NZ}$ & 6-Sep-10 & 7.1 & 46 & SS & 270 & 0.90 & 21.68 & [25] & {$[29,39]$} \\
\hline & & $\mathrm{CHHC}$ & $\begin{array}{l}\text { Christchurch, New } \\
\text { Zealand }\end{array}$ & $\mathrm{NZ}$ & 24-Feb-11 & 6.2 & 5 & RO & 196 & 0.85 & 3.02 & [25] & {$[29,39]$} \\
\hline & \multirow{2}{*}{ A2 } & Bursa Tofas & Kocaeli & Turkey & 17-Aug-99 & 7.5 & 60 & SS & 290 & 0.70 & 11.31 & [32] & {$[29,35]$} \\
\hline & & MAVS & Kaikōura & $\mathrm{NZ}$ & 14-Nov-16 & 7.8 & 96 & $\mathrm{O}$ & 390 & 0.85 & 12.97 & [25] & [39] \\
\hline & $\mathrm{A} 3$ & Talca & Valparaiso & Chile & 3-Mar-85 & 7.8 & 100 & SDI & 598 & 0.70 & 7.63 & [41] & [29] \\
\hline & $\mathrm{A} 4$ & TAPS Pump Station \#11 & Denali, Alaska & USA & 3-Nov-02 & 7.9 & 126 & SS & 376 & 0.85 & 22.58 & [32] & [29] \\
\hline & & Zone: South B & Max Z: 0.60 & & - Suite SMS & 0.83 & & & & D - & Suite SM & S: 0.7 & \\
\hline SC & HS & Station & Event & Country & Date & $\mathbf{M}$ & D & FM & $\mathbf{V}_{\mathrm{S} 30}$ & SMS & $k_{1} / \mathbf{R Z}$ & VS & SCS \\
\hline \multirow{8}{*}{$\mathrm{C}$} & \multirow{3}{*}{ B1 } & $\begin{array}{l}\text { Fremont - Mission San } \\
\text { Jose }\end{array}$ & Loma Prieta & USA & 18-Oct-89 & 6.9 & 39 & RO & 368 & 0.85 & 8.59 & [32] & [29] \\
\hline & & LPCC & Darfield, New Zealand & $\mathrm{NZ}$ & 6-Sep-10 & 7.1 & 24 & SS & 760 & 0.75 & 4.92 & [25] & {$[29,36]$} \\
\hline & & Amboy & Hector Mine & USA & 16-Oct-99 & 7.1 & 43 & SS & 383 & 0.85 & 5.90 & [32] & [29] \\
\hline & B2 & Arcelik & Kocaeli & Turkey & 17-Aug-99 & 7.5 & 13 & SS & 523 & 0.80 & 10.07 & [32] & {$[29,35]$} \\
\hline & \multirow{4}{*}{ B3 } & RDCS & Kaikōura & $\mathrm{NZ}$ & 14-Nov-16 & 7.8 & 97 & $\mathrm{O}$ & 270 & 0.90 & 18.45 & [25] & [39] \\
\hline & & TAPS Pump Station \#09 & Denali, Alaska & USA & 3-Nov-02 & 7.9 & 55 & SS & 383 & 0.90 & 18.74 & [32] & [29] \\
\hline & & CHY046 & Chi-Chi, Taiwan & Taiwan & 20-Sep-99 & 7.6 & 24 & RO & 442 & 0.90 & 5.39 & [32] & {$[29,37,38]$} \\
\hline & & Sitka Observatory & Sitka & USA & 30-Jul-72 & 7.7 & 35 & SS & 650 & 0.70 & 17.71 & {$[32]$} & [29] \\
\hline \multirow{8}{*}{$\mathrm{D}$} & \multirow{3}{*}{ B1 } & MAYC & Darfield, New Zealand & $\mathrm{NZ}$ & 6-Sep-10 & 7.1 & 46 & SS & 270 & 0.90 & 21.68 & [25] & {$[29,39]$} \\
\hline & & Desert Hot Springs & Landers & USA & 28-Jun-92 & 7.3 & 22 & SS & 359 & 0.75 & 7.92 & [32] & [29] \\
\hline & & Boshrooyeh & Tabas, Iran & Iran & 16-Sep-78 & 7.4 & 24 & $\mathrm{R}$ & 325 & 0.75 & 12.36 & [32] & [29] \\
\hline & B2 & Duzce & Kocaeli & Turkey & 17-Aug-99 & 7.5 & 15 & SS & 282 & 0.80 & 3.32 & [32] & {$[29,35]$} \\
\hline & \multirow{4}{*}{ B3 } & WAKC & Kaikōura & $\mathrm{NZ}$ & 14-Nov-16 & 7.8 & 40 & $\mathrm{O}$ & 270 & 0.85 & 6.91 & [25] & {$[29,39]$} \\
\hline & & TAPS Pump Station \#10 & Denali, Alaska & USA & 3-Nov-02 & 7.9 & 3 & SS & 329 & 0.90 & 4.37 & [32] & [29] \\
\hline & & HWA048 & Chi-Chi, Taiwan & Taiwan & 20-Sep-99 & 7.6 & 51 & RO & 346 & 0.65 & 8.36 & [32] & {$[29,37,38]$} \\
\hline & & SOCS & Kaikōura & $\mathrm{NZ}$ & 14-Nov-16 & 7.8 & 63 & $\mathrm{O}$ & 300 & 0.75 & 7.16 & [25] & {$[29,39]$} \\
\hline & & Zone: South NF & Max Z: 0.60 & & - Suite SMs & 0.81 & & & & D - & Suite SM & S: 0.8 & \\
\hline SC & HS & Station & Event & Country & Date & $\mathbf{M}$ & D & FM & $\mathbf{V}_{\mathrm{s} 30}$ & SMS & $k_{1} / \mathbf{R Z}$ & vS & SCS \\
\hline & NF1 & El Centro Array \#9 & Imperial Valley-02 & USA & 19-May-40 & 7.0 & 6 & SS & 213 & 0.90 & 4.38 & [32] & [29] \\
\hline & & Tabas* & Tabas, Iran & Iran & 16-Sep-78 & 7.4 & 2 & $\mathrm{R}$ & 767 & 0.80 & 1.17 & [32] & [29] \\
\hline & & Arcelik* & Kocaeli & Turkey & 17-Aug-99 & 7.5 & 13 & SS & 523 & 0.80 & 10.07 & [32] & {$[29,35]$} \\
\hline $\mathrm{C}$ & NF2 & LPCC & Darfield, New Zealand & $\mathrm{NZ}$ & 6-Sep-10 & 7.1 & 24 & SS & 760 & 0.75 & 4.92 & [25] & {$[29,36]$} \\
\hline & & CHY046 & Chi-Chi, Taiwan & Taiwan & 20-Sep-99 & 7.6 & 24 & RO & 442 & 0.90 & 5.39 & {$[32]$} & {$[29,37,38]$} \\
\hline & & MOLS & Kaikōura & $\mathrm{NZ}$ & 14-Nov-16 & 7.8 & 23 & $\mathrm{O}$ & 700 & 0.70 & 6.23 & [25] & {$[29,39]$} \\
\hline & NF3 & TAPS Pump Station \#09 & Denali, Alaska & USA & 3-Nov-02 & 7.9 & 55 & SS & 383 & 0.90 & 18.74 & [32] & [29] \\
\hline & NF1 & MAYC & Darfield, New Zealand & $\mathrm{NZ}$ & 6-Sep-10 & 7.1 & 46 & SS & 270 & 0.90 & 21.68 & [25] & {$[29,39]$} \\
\hline & & TCU051* & Chi-Chi, Taiwan & Taiwan & 20-Sep-99 & 7.6 & 7 & $\mathrm{R}$ & 350 & 0.85 & 6.88 & [32] & [29] \\
\hline & & Yarimca* & Kocaeli & Turkey & 17-Aug-99 & 7.5 & 5 & SS & 297 & 0.90 & 4.64 & [32] & {$[29,35]$} \\
\hline $\mathrm{D}$ & NF2 & El Centro Array \#9 & Imperial Valley-02 & USA & 19-May-40 & 7.0 & 6 & SS & 213 & 0.90 & 4.38 & [32] & [29] \\
\hline & & Boshrooyeh & Tabas, Iran & Iran & 16-Sep-78 & 7.4 & 24 & $\mathrm{R}$ & 325 & 0.75 & 12.36 & [32] & [29] \\
\hline & & GLWS & Kaikōura & $\mathrm{NZ}$ & 14-Nov-16 & 7.8 & 31 & $\mathrm{O}$ & 270 & 0.70 & 8.20 & {$[25]$} & {$[29,39]$} \\
\hline & NF3 & TAPS Pump Station \#10 & Denali, Alaska & USA & 3-Nov-02 & 7.9 & 3 & SS & 329 & 0.90 & 4.37 & [32] & [29] \\
\hline
\end{tabular}


Table 2: Default record suites (Bold corresponds to New Zealand records recorded in the same geographic area of the zone).

\begin{tabular}{|c|c|c|c|c|c|c|c|c|c|c|c|c|c|}
\hline & \multirow{2}{*}{\multicolumn{2}{|c|}{$\begin{array}{ll} & \text { Zone: South K } \\
\text { HS Station }\end{array}$}} & \multirow{2}{*}{$\begin{array}{l}\text { Max Z: } 0.55 \\
\text { Event }\end{array}$} & \multicolumn{5}{|c|}{ C - Suite SMS: 0.77} & \multicolumn{5}{|c|}{ D - Suite SMS: 0.82} \\
\hline SC & & & & Country & Date & $\mathbf{M}$ & D & FM & $\mathbf{V}_{\mathrm{S} 30}$ & SMS & $k_{1} / \mathbf{R Z}$ & VS & SCS \\
\hline \multirow{7}{*}{$\mathrm{C}$} & \multirow{2}{*}{ K1 } & Geotech Investig Center & San Salvador & El Salv & $10-$ Oct- 86 & 5.8 & 6 & SS & 489 & 0.85 & 1.56 & [32] & [29] \\
\hline & & TCU122 & Chi-Chi, Taiwan-03 & Taiwan & 20-Sep-99 & 6.2 & 19 & $\mathrm{R}$ & 475 & 0.90 & 5.40 & [32] & [29] \\
\hline & \multirow{4}{*}{ K2 } & El Centro Array \#9 & Imperial Valley-02 & USA & 19-May-40 & 7.0 & 6 & SS & 213 & 0.80 & 3.40 & [32] & {$[8]$} \\
\hline & & MOLS & Kaikōura & $\mathrm{NZ}$ & 14-Nov-16 & 7.8 & 23 & $\mathrm{O}$ & 700 & 0.70 & 6.23 & [25] & {$[29,39]$} \\
\hline & & Tabas* & Tabas, Iran & Iran & 16-Sep-78 & 7.4 & 2 & $\mathrm{R}$ & 767 & 0.80 & 1.17 & [32] & [29] \\
\hline & & Arcelik* & Kocaeli & Turkey & 17-Aug-99 & 7.5 & 13 & SS & 523 & 0.80 & 10.07 & [32] & {$[29,35]$} \\
\hline & K3 & $\begin{array}{l}\text { Valparaiso Almendral } \\
\text { (VAL) }\end{array}$ & Valparaiso & Chile & 3-Mar-85 & 7.8 & 37 & SDI & 360 & 0.55 & 3.45 & [40] & {$[40]$} \\
\hline \multirow{7}{*}{$\mathrm{D}$} & \multirow[t]{2}{*}{ K1 } & $\mathrm{CHHC}$ & $\begin{array}{l}\text { Christchurch, New } \\
\text { Zealand }\end{array}$ & $\mathrm{NZ}$ & 24-Feb-11 & 6.2 & 5 & RO & 196 & 0.85 & 3.02 & [25] & {$[29,39]$} \\
\hline & & Chihuahua & Victoria & Mexico & $24-$ Oct- 80 & 6.3 & 19 & SS & 242 & 0.85 & 7.79 & [32] & [29] \\
\hline & \multirow{4}{*}{ K2 } & El Centro Array \#9 & Imperial Valley-02 & USA & 19-May-40 & 7.0 & 6 & SS & 213 & 0.90 & 4.38 & [32] & [29] \\
\hline & & TCU051* & Chi-Chi, Taiwan & Taiwan & 20-Sep-99 & 7.6 & 7 & $\mathrm{R}$ & 350 & 0.85 & 6.88 & [32] & [29] \\
\hline & & Yarimca* & Kocaeli & Turkey & 17-Aug-99 & 7.5 & 5 & SS & 297 & 0.90 & 4.64 & [32] & {$[29,35]$} \\
\hline & & GLWS & Kaikōura & $\mathrm{NZ}$ & 14-Nov-16 & 7.8 & 31 & $\mathrm{O}$ & 270 & 0.70 & 8.20 & [25] & {$[29,39]$} \\
\hline & K3 & Llolleo & Valparaiso & Chile & 3-Mar-85 & 7.8 & 23 & SDI & 305 & 0.80 & 2.06 & [40] & {$[40]$} \\
\hline \multirow[b]{2}{*}{ SC } & & Zone: South C & Max Z: 0.30 & \multicolumn{5}{|c|}{ C - Suite SMS: 0.79} & \multicolumn{5}{|c|}{ D - Suite SMS: 0.83} \\
\hline & HS & Station & Event & Country & Date & $\mathbf{M}$ & D & FM & $\mathbf{V}_{\mathbf{S 3 0}}$ & SMS & $k_{1} / \mathbf{R Z}$ & VS & SCS \\
\hline \multirow{7}{*}{$\mathrm{C}$} & $\mathrm{C} 1$ & Geotech Investig Center & San Salvador & El Salv & $10-$ Oct- 86 & 5.8 & 6 & SS & 489 & 0.85 & 1.56 & [32] & [29] \\
\hline & \multirow{3}{*}{$\mathrm{C} 2$} & El Centro Array \#9 & Imperial Valley-02 & USA & 19-May-40 & 7.0 & 6 & SS & 213 & 0.80 & 3.40 & [32] & {$[8]$} \\
\hline & & RHSC & $\begin{array}{l}\text { Christchurch, New } \\
\text { Zealand }\end{array}$ & $\mathrm{NZ}$ & 22-Feb-11 & 6.2 & 10 & RO & 286 & 0.60 & 2.95 & [25] & {$[36]$} \\
\hline & & TCU122 & Chi-Chi, Taiwan-03 & Taiwan & 20-Sep-99 & 6.2 & 19 & $\mathrm{R}$ & 475 & 0.90 & 5.40 & [32] & [29] \\
\hline & $C_{3}$ & LPCC & Darfield, New Zealand & $\mathrm{NZ}$ & 6-Sep-10 & 7.1 & 24 & SS & 760 & 0.75 & 4.92 & [25] & {$[29,36]$} \\
\hline & C3 & MOLS & Kaikōura & $\mathrm{NZ}$ & 14-Nov-16 & 7.8 & 23 & $\mathrm{O}$ & 700 & 0.70 & 6.23 & [25] & {$[29,39]$} \\
\hline & $\mathrm{C} 4$ & TAPS Pump Station \#11 & Denali, Alaska & USA & 3-Nov-02 & 7.9 & 126 & SS & 376 & 0.95 & 17.55 & [32] & [29] \\
\hline \multirow{8}{*}{$\mathrm{D}$} & $\mathrm{C} 1$ & Gilroy Array \#4 & Coyote Lake & USA & 6-Aug-79 & 5.7 & 6 & SS & 222 & 0.65 & 5.29 & [32] & [29] \\
\hline & \multirow{3}{*}{$\mathrm{C} 2$} & El Centro Array \#9 & Imperial Valley-02 & USA & 19-May-40 & 7.0 & 6 & SS & 213 & 0.90 & 4.38 & [32] & [29] \\
\hline & & Chihuahua & Victoria & Mexico & $24-O c t-80$ & 6.3 & 19 & SS & 242 & 0.85 & 7.79 & [32] & [29] \\
\hline & & СHHC & $\begin{array}{l}\text { Christchurch, New } \\
\text { Zealand }\end{array}$ & $\mathrm{NZ}$ & 24-Feb-11 & 6.2 & 5 & RO & 196 & 0.85 & 3.02 & [25] & {$[29,39]$} \\
\hline & & ROLC & Darfield, New Zealand & $\mathrm{NZ}$ & 6-Sep-10 & 7.1 & 2 & SS & 210 & 1.00 & 4.96 & [25] & {$[29,39]$} \\
\hline & C3 & CECS & Kaikōura & $\mathrm{NZ}$ & 14-Nov-16 & 7.8 & 27 & $\mathrm{O}$ & 270 & 0.70 & 3.70 & [25] & {$[29,39]$} \\
\hline & $\mathrm{C} 4$ & TAPS Pump Station \#11 & Denali, Alaska & USA & 3-Nov-02 & 7.9 & 126 & SS & 376 & 0.85 & 22.58 & [32] & {$[29]$} \\
\hline & & Zone: South D & Max Z: 0.55 & & - Suite SMS & 0.79 & & & & D - & Suite SM & IS: 0.8 & \\
\hline SC & HS & Station & Event & Country & Date & $\mathbf{M}$ & D & $\mathbf{F M}$ & $\mathbf{V}_{\mathrm{S30}}$ & SMS & $k_{1} / \mathbf{R Z}$ & VS & SCS \\
\hline & & El Centro Array \#9 & Imperial Valley-02 & USA & 19-May-40 & 7.0 & 6 & SS & 213 & 0.80 & 3.40 & [32] & {$[8]$} \\
\hline & D1 & $\begin{array}{l}\text { Bear Valley \#5, Callens } \\
\text { Ranch }\end{array}$ & Loma Prieta & USA & 18 -Oct-89 & 6.9 & 53 & RO & 391 & 0.95 & 14.26 & [32] & [29] \\
\hline & DI & RHSC & $\begin{array}{l}\text { Christchurch, New } \\
\text { Zealand }\end{array}$ & $\mathrm{NZ}$ & 22-Feb-11 & 6.2 & 10 & RO & 286 & 0.60 & 2.95 & [25] & {$[36]$} \\
\hline $\mathrm{C}$ & & TRCS & Darfield, New Zealand & $\mathrm{NZ}$ & 6-Sep-10 & 7.1 & 104 & SS & 690 & 0.65 & 17.80 & [25] & {$[29,39]$} \\
\hline & $\mathrm{D} 2$ & HWA017 & Chi-Chi, Taiwan & Taiwan & 20-Sep-99 & 7.6 & 51 & RO & 578 & 0.75 & 11.26 & {$[32]$} & {$[29,37,38]$} \\
\hline & D3 & Talca & Valparaiso & Chile & 3-Mar-85 & 7.8 & 100 & SDI & 598 & 0.80 & 5.93 & [41] & [29] \\
\hline & $\mathrm{D} 4$ & TAPS Pump Station \#11 & Denali, Alaska & USA & 3-Nov-02 & 7.9 & 126 & SS & 376 & 0.95 & 17.55 & [32] & [29] \\
\hline & D4 & POKS & Kaikōura & NZ & 14-Nov-16 & 7.8 & 66 & $\mathrm{O}$ & 330 & 0.80 & 9.35 & [25] & [39] \\
\hline & & El Centro Array \#9 & Imperial Valley-02 & USA & 19-May-40 & 7.0 & 6 & SS & 213 & 0.90 & 4.38 & [32] & [29] \\
\hline & & Compton - Castlegate St & Northridge-01 & USA & 17-Jan-94 & 6.7 & 47 & $\mathrm{R}$ & 266.9 & 0.75 & 12.46 & [32] & [29] \\
\hline & D1 & LSRC & $\begin{array}{l}\text { Christchurch, New } \\
\text { Zealand }\end{array}$ & $\mathrm{NZ}$ & 22-Feb-11 & 6.2 & 74 & RO & 270 & 0.95 & 33.46 & [25] & [29] \\
\hline D & & MAYC & Darfield, New Zealand & $\mathrm{NZ}$ & 6-Sep-10 & 7.1 & 46 & SS & 270 & 0.90 & 21.68 & [25] & {$[29,39]$} \\
\hline & D2 & Bursa Tofas & Kocaeli & Turkey & 17-Aug-99 & 7.5 & 60 & SS & 290 & 0.70 & 11.31 & [32] & {$[29,35]$} \\
\hline & D3 & Talca & Valparaiso & Chile & 3-Mar-85 & 7.8 & 100 & SDI & 598 & 0.70 & 7.63 & [41] & [29] \\
\hline & $\mathrm{D} 4$ & TAPS Pump Station \#11 & Denali, Alaska & USA & 3-Nov-02 & 7.9 & 126 & SS & 376 & 0.85 & 22.58 & [32] & [29] \\
\hline & D4 & CSTC & Kaikōura & $\mathrm{NZ}$ & 14-Nov-16 & 7.8 & 87 & $\mathrm{O}$ & 425 & 0.85 & 33.91 & [25] & [29] \\
\hline
\end{tabular}


Table 2: Default record suites (Bold corresponds to New Zealand records recorded in the same geographic area of the zone).

\begin{tabular}{|c|c|c|c|c|c|c|c|c|c|c|c|c|c|}
\hline \multirow[b]{2}{*}{ SC } & \multirow[b]{2}{*}{ HS } & \multirow{2}{*}{$\begin{array}{l}\text { Zone: South E } \\
\text { Station }\end{array}$} & \multirow{2}{*}{$\begin{array}{l}\text { Max Z: } 0.2 \\
\text { Event }\end{array}$} & \multicolumn{5}{|c|}{ C - Suite SMS: 0.77} & \multicolumn{5}{|c|}{ D - Suite SMS: 0.85} \\
\hline & & & & Country & Date & $\mathbf{M}$ & D & FM & $\mathbf{V}_{\mathrm{S30}}$ & SMS & $k_{1} / \mathbf{R Z}$ & VS & SCS \\
\hline \multirow{7}{*}{$\mathrm{C}$} & \multirow{3}{*}{ E1 } & El Centro Array \#9 & Imperial Valley-02 & USA & 19-May-40 & 7.0 & 6 & SS & 213 & 0.80 & 3.40 & [32] & {$[8]$} \\
\hline & & $\begin{array}{l}\text { Fremont - Mission San } \\
\text { Jose }\end{array}$ & Loma Prieta & USA & 18 -Oct-89 & 6.9 & 39 & RO & 367.6 & 0.85 & 8.59 & [32] & [29] \\
\hline & & RHSC & $\begin{array}{l}\text { Christchurch, New } \\
\text { Zealand }\end{array}$ & $\mathrm{NZ}$ & 22-Feb-11 & 6.2 & 10 & $\mathrm{RO}$ & 286 & 0.60 & 2.95 & [25] & [36] \\
\hline & \multirow{2}{*}{ E2 } & TRCS & Darfield, New Zealand & $\mathrm{NZ}$ & 6-Sep-10 & 7.1 & 104 & SS & 690 & 0.65 & 17.80 & [25] & {$[29,39]$} \\
\hline & & HWA017 & Chi-Chi, Taiwan & Taiwan & 20-Sep-99 & 7.6 & 51 & RO & 578 & 0.75 & 11.26 & [32] & {$[29,37,38]$} \\
\hline & \multirow{2}{*}{ E3 } & MENS & Kaikōura & $\mathrm{NZ}$ & 14-Nov-16 & 7.8 & 105 & $\mathrm{O}$ & 690 & 0.80 & 36.22 & [25] & {$[29,39]$} \\
\hline & & TAPS Pump Station \#11 & Denali, Alaska & USA & 3-Nov-02 & 7.9 & 126 & SS & 376 & 0.95 & 17.55 & [32] & [29] \\
\hline \multirow{7}{*}{ D } & \multirow{3}{*}{ E1 } & El Centro Array \#9 & Imperial Valley-02 & USA & 19-May-40 & 7.0 & 6 & SS & 213 & 0.90 & 4.38 & [32] & [29] \\
\hline & & LB - Rancho Los Cerritos & Northridge- 01 & USA & 17-Jan-94 & 6.7 & 52 & $\mathrm{R}$ & 302.7 & 0.85 & 17.24 & [32] & [29] \\
\hline & & LSRC & $\begin{array}{l}\text { Christchurch, New } \\
\text { Zealand }\end{array}$ & $\mathrm{NZ}$ & 22-Feb-11 & 6.2 & 74 & RO & 270 & 0.95 & 33.46 & [25] & [39] \\
\hline & \multirow{2}{*}{$\mathrm{E} 2$} & PEEC & Darfield, New Zealand & $\mathrm{NZ}$ & 6-Sep-10 & 7.1 & 64 & SS & 425 & 0.80 & 11.25 & [25] & [39] \\
\hline & & ILA013 & Chi-Chi, Taiwan & Taiwan & 20-Sep-99 & 7.6 & 84 & RO & 200 & 0.75 & 7.43 & [32] & {$[29,37,38]$} \\
\hline & \multirow{2}{*}{ E3 } & CSTC & Kaikōura & $\mathrm{NZ}$ & 14-Nov-16 & 7.8 & 87 & $\mathrm{O}$ & 425 & 0.85 & 33.91 & [25] & [39] \\
\hline & & TAPS Pump Station \#11 & Denali, Alaska & USA & 3-Nov-02 & 7.9 & 126 & SS & 376 & 0.85 & 22.58 & [32] & [29] \\
\hline & \multicolumn{4}{|c|}{$\begin{array}{l}\text { Max } Z=\text { maximum hazard factor in specified zone } \\
S C=\text { site class according to the } S t a n d a r d \\
H S=\text { hazard scenario (see Table } 1 \text { ) } \\
*=\text { record has forward directivity characteristics } \\
M=\text { magnitude in } M_{w} \\
D=\text { distance in } \mathrm{km} \text { from the rupture plane }\left(\mathrm{R}_{\mathrm{RUP}}\right) \\
\mathrm{FM}=\text { fault mechanism, } \mathrm{SS}=\text { strike-slip, } \mathrm{R}=\text { reverse, } \mathrm{O}=\text { oblique }\end{array}$} & \multicolumn{9}{|c|}{$\begin{array}{l}\mathrm{RO}=\text { reverse-oblique, } \mathrm{SDI}=\text { subduction interface } \\
\mathrm{V}_{\mathrm{S} 30}=\text { average shear wave velocity over the top } 30 \mathrm{~m}, \mathrm{in} \mathrm{m} / \mathrm{s} \\
\mathrm{SMS}=\text { spectral matching score } \\
k_{1} / \mathrm{RZ}=\text { Record scale factor }(\text { for a natural period of } 0.5 \mathrm{sec} \text { ) assuming } \\
\text { return period factor and hazard factor both equal } 1 . \\
\mathrm{VS}=\mathrm{V}_{\mathrm{S} 30} \text { reference } \\
\mathrm{SCS}=\text { site class reference }\end{array}$} \\
\hline
\end{tabular}

\section{LIMITATIONS FOR USE OF THE RECOMMENDED RECORDS SUITES}

The hazard analysis in this paper has been carried out using the 2010 National Seismic Hazard Model, the Canterbury Seismic Hazard Model, and the Kaikōura Seismic Hazard Model (2010 NSHM, CSHM, and KSHM, respectively). Both the source models and the McVerry et al [18] ground motion prediction model used in the 2010 NSHM are now dated, but are used to be consistent with the NZS1170.5 Standard.

The zones were selected to represent regions of similar seismological characteristics, but when the deaggregation results were obtained they showed that for some zones there were differences in the magnitude-distance combinations contributing to the hazard at locations within the zones.

In particular, there was considerable variation between the deaggregations for different locations in each of the large zones South D and E. Site-specific studies are highly recommended for these two zones, in particular. However, in absence of a site-specific study, the default records in this study may be used for provisional design or assessment, but care should be exercised in applying the recommended suites for these two zones. Similarly, the nature of the deaggregations for Nelson differ from those for the other two selected locations, Takaka and Westport, in Zone South A, with the hazard for Nelson being dominated more by large faults, similar to Blenheim. However, Nelson falls outside of the previously discussed region of heightened seismic activity due to the 2016 Kaikōura earthquake $[21,22]$ and thus was instead included in Zone South A.

It is important to note that the ground motion selection and scaling requirements presented in the Standard [6] are outdated (at least 17 years old) and have important limitations that are significantly behind more contemporary approaches, as discussed specifically for the Standard by Morris et. al. [30] Similarly, a variety of seismic hazard models developed over a twenty-year period were considered in this study.
Deaggregations carried out using the 2010 NSHM [11] were used to select records scaled to match the NZS1170.5 spectra, which is based on the 2002 NSHM model [12], except in the Canterbury Earthquake and Kaikoura regions where the CSHM [14], and the KSHM [20,21] models were used, respectively.

Furthermore, secondary intensity measures, such as significant duration, peak ground velocity, and Arias intensity were not considered in the selection of the recommended record suites. While such measures can be important for NLTHA record selection $[45,46]$, they are beyond the scope of this study's goal of creating a tool for practicing structural engineers. If a specific project or site requires careful consideration of such measures, the authors recommend a site-specific study.

Another issue is that the seismic hazard analysis was carried out without consideration of epistemic uncertainties in the GMPEs. Except for the Canterbury Earthquake region and the Kaikōura region, only one GMPE (McVerry et al., 2006) was used, to be consistent with NZS1170.5, which is based on the 2002 NSHM model. Even though consideration of epistemic uncertainties is not required in the Standard, it has been included as a requirement in New Zealand's Dam Safety Guidelines [23] and is consistent with international best practice. Future updates of this database should consider using a GMPE logic tree to address epistemic uncertainties in the ground motion, for example the one recommended for New Zealand by Van Houtte [24], which includes several NGA-West2 GMPEs and the New Zealand Bradley GMPE [19].

Although the ground-motion records suite profiles as presented in Table 1 are valid for buildings with fundamental periods of between 0.4 and 2.0 seconds in all soil site classes, the suites presented in Table 2 are for use in soil site classes C and D only (as defined by the Standard). It should also be noted that the periods selected in the scoring framework outlined within present a slight bias towards structures in the middle of the period range, with the mean of the periods considered equal to 1.1 seconds. While this is not necessarily representative of the 
building stock, it does aim to be representative of the buildings that require NLTHA.

The ground-motion records suites shall only be used in full; in other words, and notwithstanding the reduced number of records currently required by the Standard [6] for NLTHA, all seven or eight ground-motion records in each suite should be used. These records were developed for standard building design and assessment (in accordance with the Standard), and are not intended to be used for other types of structures (e.g., bridges, monuments, industrial infrastructure, etc.). Sitespecific studies are highly recommended, especially in locations outside those considered in the deaggregation process presented in this paper, and for high-risk buildings (e.g., importance level 4). However, in absence of a site-specific study, the default records in this study may be used for provisional design or assessment.

\section{SUMMARY AND RECOMMENDATIONS}

A seismic hazard zonation and ground-motion record selection was carried out for use in time-history analysis of buildings located in selected locations in the South Island of New Zealand, based on characteristics related to seismological signature (i.e. the magnitudes, shortest distances, and types of earthquakes that significantly contribute to the estimated 500year hazard exceedance rates). Eight zones were defined in terms of deaggregations and the hazard factor map contours and near-fault effects as presented in the Standard [6]. A description of the appropriate records for each zone, along with general criteria for the selection of actual ground-motion records was presented. Specific suites of records were recommended for each zone.

Important parts of this study to comment on include:

- The results of this study are not relevant for seismic design and assessment of buildings with fundamental periods outside of the defined range of 0.4 to 2.0 seconds;

- The study has been performed for a return period of 500 years. The deaggregations are likely to change for other return periods, so caution should be used in using the results for other return periods;

- The suite profiles presented in Table 1 are valid for all five of the site classes in the Standard; however, the recommended suites of records in Table 2 are only applicable for site classes C and D (shallow and deep soil, respectively) as these constitute the majority of building projects in the South Island; and

- The zone boundaries, suite profiles and recommended suites of records for each zone should be updated periodically, according to amendments or requirements of the Standard (for example, revision of the major faults) and state-of-the-art knowledge (probabilistic seismic hazard model actualization). Similarly, future updates could consider expanding the scope of work to a wider range of site classes, fundamental periods, or return periods.

\section{ACKOWLEDGMENTS}

The authors would like to acknowledge the data-mining carried out by various undergraduate researchers including Matthew Cheyne and Simon Ferris at the University of Auckland (NZ) and Benjamin Wallace at the University of Notre Dame (USA), as well as the insights on practical application provided by Andrew O'Donnell of AIR Worldwide (Boston, MA, USA). The authors wish to thank Elizabeth Abbott (GNS Science) for reviewing this manuscript and the managers of the PEER, GeoNet, K-NET, and COSMOS strong-motion databases for providing the records. The authors also acknowledge the New Zealand GeoNet project and its sponsors EQC, GNS Science, and LINZ, for providing data used in this study.

\section{REFERENCES}

1 Gebelein J, Barnard M, Burton H, Cochran M, Haselton C, McLellan R and Porter K (2017). "Considerations for a framework of resilient structural design for earthquakes". SEAOC 2017 Convention, 13-16 September, San Diego, California, $16 \mathrm{pp}$.

https://cdn.ymaws.com/www.seaoc.org/resource/resmgr/C onvention_Proceedings/2017/047_PAPER_Gebelein.pdf

2 SEAOC (1996). "Vision 2000, Conceptual Framework for Performance-Based Seismic Design, Recommended Lateral Force Requirements and Commentary, 6th Edition". Structural Engineers Association of California (SEAOC), Sacramento, California.

3 Almufti I and Willford M (2013). "Resilience-Based Earthquake Design Initiative for the Next Generation of Buildings, REDi”. Arup, San Francisco, California, 133 pp. https://www.arup.com/perspectives/publications/research/s ection/redi-rating-system

4 FEMA (2018). "Seismic Performance Assessment of Buildings, FEMA P-58-1." Federal Emergency Management Agency (FEMA), Washington, DC, 340 pp. http://femap58.atcouncil.org/

5 USRC (2019). “Implementation Manual: USRC Building Rating System for Earthquake Hazards”. U.S. Resiliency Council (USRC), San Francisco, California, 130 pp.

6 Standards New Zealand (2016a). "NZS 1170.5: Structural Design Actions. Part 5: Earthquake Actions". Standards New Zealand, Wellington, 133 pp.

https://www.standards.govt.nz/sponsoredstandards/building-standards/nzs1170-5/

7 Standards New Zealand (2016b). "NZS 1170.5: Structural Design Actions. Part 5: Earthquake Actions-Commentary". Standards New Zealand, Wellington, 133 pp. https://www.standards.govt.nz/sponsoredstandards/building-standards/nzs1170-5/

8 Oyarzo-Vera CA, McVerry G and Ingham JM (2012). "Seismic zonation and default suite of ground-motion records for time-history analysis in the North Island of New Zealand". Earthquake Spectra, 28(2): 667-688. https://doi.org/10.1193\%2F1.4000016

9 Iervolino I, Galasso C and Cosenza E (2010). "REXEL: Computer aided record selection for code-based seismic structural analysis". Bulletin of Earthquake Engineering, 8: 339-362. https://doi.org/10.1007/s10518-009-9146-1

10 Christophersen A, Gerstenberger M, Rhoades D and Stirling M (2011). "Quantifying the effect of declustering on probabilistic seismic hazard". Ninth Pacific Conference on Earthquake Engineering, 14-16 April, Auckland, New Zealand, Paper No 206, 8pp. https://www.nzsee.org.nz/db/2011/206.pdf

11 Stirling M, McVerry G, Gerstenberger M, Litchfield N, Van Dissen R, Berryman K, Barnes P, Wallace L, Villamor P, Langridge R, Lamarche G, Nodder S, Reyners M, Bradley B, Rhoades D, Smith W, Nicol A, Pettinga J, Clark $\mathrm{K}$ and Jacobs K (2012). "National seismic hazard model for New Zealand: 2010 update". Bulletin of the Seismological Society of America, 102(4): 1514-1542. https://doi.org/10.1785/0120110170

12 Stirling M, McVerry G and Berryman K (2002). "A new seismic hazard model for New Zealand". Bulletin of the Seismological Society of America, 92(5): 1878-1903. https://doi.org/10.1785/0120010156 
13 DBH (2011). "Compliance document for New Zealand Building Code: Clause B1”. Department of Building and Housing (DBH), Wellington, 94 pp. https://www.building.govt.nz/assets/Uploads/buildingcode-compliance/b-stability/b1-structure/asvm/b1structure-1st-edition-amendment-10.pdf

14 Gerstenberger M, McVerry G, Rhoades D and Stirling M (2014). "Seismic hazard modeling for the recovery of Christchurch." Earthquake Spectra, 30(1): 17-29. https://doi.org/10.1193/021913EQS037M

15 Gerstenberger M, Rhoades D and McVerry G (2016). “A hybrid time-dependent probabilistic seismic-hazard model for Canterbury, New Zealand". Seismological Research Letters, 87(6): 1311-1318. https://doi.org/10.1785/0220160084

16 Haselton CB, Whittaker AS, Hotacsu A, Baker JW, Bray J and Grant DN (2012). "Selecting and scaling earthquake ground motions for performing response-history analysis". World Conference on Earthquake Engineering, 24-28 September, Lisbon, Portugal, 10pp. https://cutt.ly/EfNr5Eu

17 NIST (2011). "Selecting and Scaling Earthquake Ground Motions for Performing Response-History Analyses, NIST GCR 11 -917-15”. National Institute of Standards and Technology (NIST), Gaithersburg, Maryland, $256 \mathrm{pp}$. https://www.nist.gov/publications/selecting-and-scalingearthquake-ground-motions-performing-response-historyanalyses

18 McVerry G, Zhao JX, Abrahamson NA and Somerville PG (2006). "New Zealand acceleration response spectrum attenuation relations for crustal and subduction zone earthquakes". Bulletin of the New Zealand Society for Earthquake Engineering, 39(1): 1-58. https://doi.org/10.5459/bnzsee.39.1.1-58

19 Bradley B (2013). “A New Zealand-specific pseudospectral acceleration ground-motion prediction equation for active shallow crustal earthquakes based on foreign models". Bulletin of the Seismological Society of America, 103(3): 1801-1822. https://doi.org/10.1785/0120120021

20 Goded T, Gerstenberger MC, Litchfield NJ, McVerry GH, Lukovic B, Van Dissen RJ, Rhoades DA, Holden C, Langridge RM and Christophersen A (2018). "Seismic Hazard Analysis for State Highway 1 and An Alternative Route Following the 2016 Kaikôra Earthquake". GNS Science Consultancy Report 2018/114, GNS Science, Lower Hutt, 83 pp + 240 maps.

21 Gerstenberger M, Rhoades D, Litchfield N, Kaiser A, Holden C, Fry B, Van Dissen R, McVerry G, Goded T and Stirling M (2021). "A time-dependent seismic hazard model for Kaikōura, New Zealand”. (in preparation).

22 Litchfield NJ, Villamor P, Van Dissen RJ, Nicol A, Barnes PM, Barrell DJA, Pettinga J, Langridge RM, Little TA and Mountjoy J (2018). "Surface rupture of multiple crustal faults in the $2016 \mathrm{Mw} 7.8$ Kaikōura, New Zealand, earthquake". Bulletin of the Seismological Society of America, 108(3b): 1496-1520. https://doi.org/10.1785/0120170300

23 NZSOLD (2015). "New Zealand Dam Safety Guidelines". New Zealand Society on Large Dams (NZSOLD), Wellington. $\quad$ https://nzsold.org.nz/wpcontent/uploads/2017/08/nzsold_dam_safety_guidelines$\underline{\text { may-2015.pdf }}$

24 Van Houtte C (2017). "Performance of response spectral models against New Zealand data”. Bulletin of New Zealand Society for Earthquake Engineering, 50(1): 21-38. https://doi.org/10.5459/bnzsee.50.1.21-38
25 Van Houtte C, Bannister S, Holden C, Bourguignon S and McVerry G (2017). "The New Zealand strong motion database". Bulletin of the New Zealand Society for Earthquake Engineering, 50(1): 1-20.

https://doi.org/10.5459/bnzsee.50.1.1-20

26 Standards New Zealand (2004). "NZS 1170.5: Structural Design Actions. Part 5: Earthquake Actions". Standards New Zealand, Wellington, 133 pp. https://www.standards.govt.nz/sponsoredstandards/building-standards/nzs1170-5/

27 CEN (2004). "Eurocode 8: Design of Structures for Earthquake Resistance-Part 1: General Rules, Seismic Actions and Rules for Buildings". Comité Européen de Normalisation (CEN), Brussels, Belgium.

28 ASCE (2010). "Minimum Design Loads and Associated Criteria for Buildings and Other Structures, ASCE/SEI 710”. American Society of Civil Engineers (ASCE), Reston, Virginia.

29 ASCE (2016). "Minimum Design Loads and Associated Criteria for Buildings and Other Structures, ASCE/SEI 716". American Society of Civil Engineers (ASCE), Reston, Virginia.

30 Morris GJ, Thompson AJ, Dismuke JN and Bradley BA (2019). "Ground motion input for nonlinear response history analysis: Practical limitations of NZS 1170.5 and comparison to US standards". Bulletin of the New Zealand Society for Earthquake Engineering, 52(3): 119-133. https://doi.org/10.5459/bnzsee.52.3.119-133

31 Kyoshin Network (K-NET) (2010). Japan Strong-Motion Data Center. http://www.k-net.bosai.go.jp/k-net. (Accessed 15 August 2019).

32 Pacific Earthquake Engineering Research (PEER) Center (2013). PEER NGA-West2Ground Motion Database. https://ngawest2.berkeley.edu/ (Accessed 14 August 2019).

33 Consortium of Organizations for Strong-Motion Observation System (COSMOS) (2012). Strong-Motion Virtual Data Center. http://www.strongmotioncenter.org/vdc/ $\quad$ Accessed 10 August 2019).

34 Earthquake Commission (EQC) New Zealand and GNS Science (2017). New Zealand Strong-Motion Database. https://www.geonet.org.nz/data/supplementary/nzsmdb (last accessed 15 August 2019).

35 Rathje EM, Stokoe KH and Rosenblad B (2003). "Strong motion station characterization and site effects during the 1999 earthquakes in Turkey”. Earthquake Spectra, 19(3): 653-675. https://doi.org/10.1193/1.1596212

36 Wood CM, Cox BR, Wotherspoon LM and Green AG (2011). "Dynamic site characterization of Christchurch strong motion stations". Bulletin of the New Zealand Society for Earthquake Engineering, 44(4): 195-204. https://doi.org/10.5459/bnzsee.44.4.195-204

37 Kuo CH, Wen KL, Hsieh HH, Lin CM, Chang TM and Kuo KW (2012). "Site Classification and Vs30 estimation of free-field TSMIP stations using the logging data of EGDT". Engineering Geology, 129-130: 68-75. https://doi.org/10.1016/j.enggeo.2012.01.013

38 Kuo CH, Lin CM, Wen KL and Hsieh HH (2016). "An Important Update for the Engineering Geological Database for TSMIP". National Center for Research on Earthquake Engineering (NCREE), Taipei, Taiwan.

39 Kaiser A, Van Houtte C, Perrin N, Wotherspoon L and McVerry G (2017). "Site characterisation of GeoNet stations for the New Zealand strong motion database". Bulletin of the New Zealand Society for Earthquake Engineering, 50(1): 39-49.

https://doi.org/10.5459/bnzsee.50.1.39-49 
40 Boroschek RL, Contreras V, Kwak DY and Stewart JP (2012). "Strong ground motion attributes of the $2010 \mathrm{Mw}$ 8.8 Maule, Chile, Earthquake". Earthquake Spectra, 28(1): S19-S38. https://doi.org/10.1193/1.4000045

41 Yang S, Mavroeidis GP, de la Llera JC, Poulous A, Rahpeyma S, Sonnemann T and Halldorsson B (2019). "Empirical site classification of seismological stations in Chile using horizontal-to-vertical spectral ratios determined from recordings of large subduction-zone earthquakes". Soil Dynamics and Earthquake Engineering, 125. https://doi.org/10.1016/j.soildyn.2019.05.017

42 Shome N, Cornell CA, Bazzurro P and Carballo JE (1998). "Earthquakes, records, and nonlinear responses". Earthquake Spectra, 14(3): 469-500. https://doi.org/10.1193/1.1586011

43 Iervolino I and Cornell CA (2005). "Record selection for nonlinear seismic analysis of structures". Earthquake Spectra, 21(3): 685-713. https://doi.org/10.1193/1.1990199
44 Luco N and Bazzurro P (2007). "Does amplitude scaling of ground motion records result in biased nonlinear structural drift responses?". Earthquake Engineering and Structural Dynamics 36(13): 1813-1835. https://doi.org/10.1002/eqe.695

45 Kohrangi M, Vamvatsikos D and Bazzurro P (2016). "Implications of intensity measure selection for seismic loss assessment of 3-D buildings". Earthquake Spectra, 32(4): 2167-2189. https://doi.org/10.1193/112215EQS177M

46 Stafford PJ, Berrill JB and Pettinga JR (2009) "New predictive equations for Arias intensity from crustal earthquakes in New Zealand". Journal of Seismology, 13: 31-52. https://doi.org/10.1007/s10950-008-9114-2

47 Seed HB and Idriss IM (1982). "Ground Motions and Soil Liquefaction during Earthquakes". Monograph MNO-5, Earthquake Engineering Research Institute, Oakland, California. 


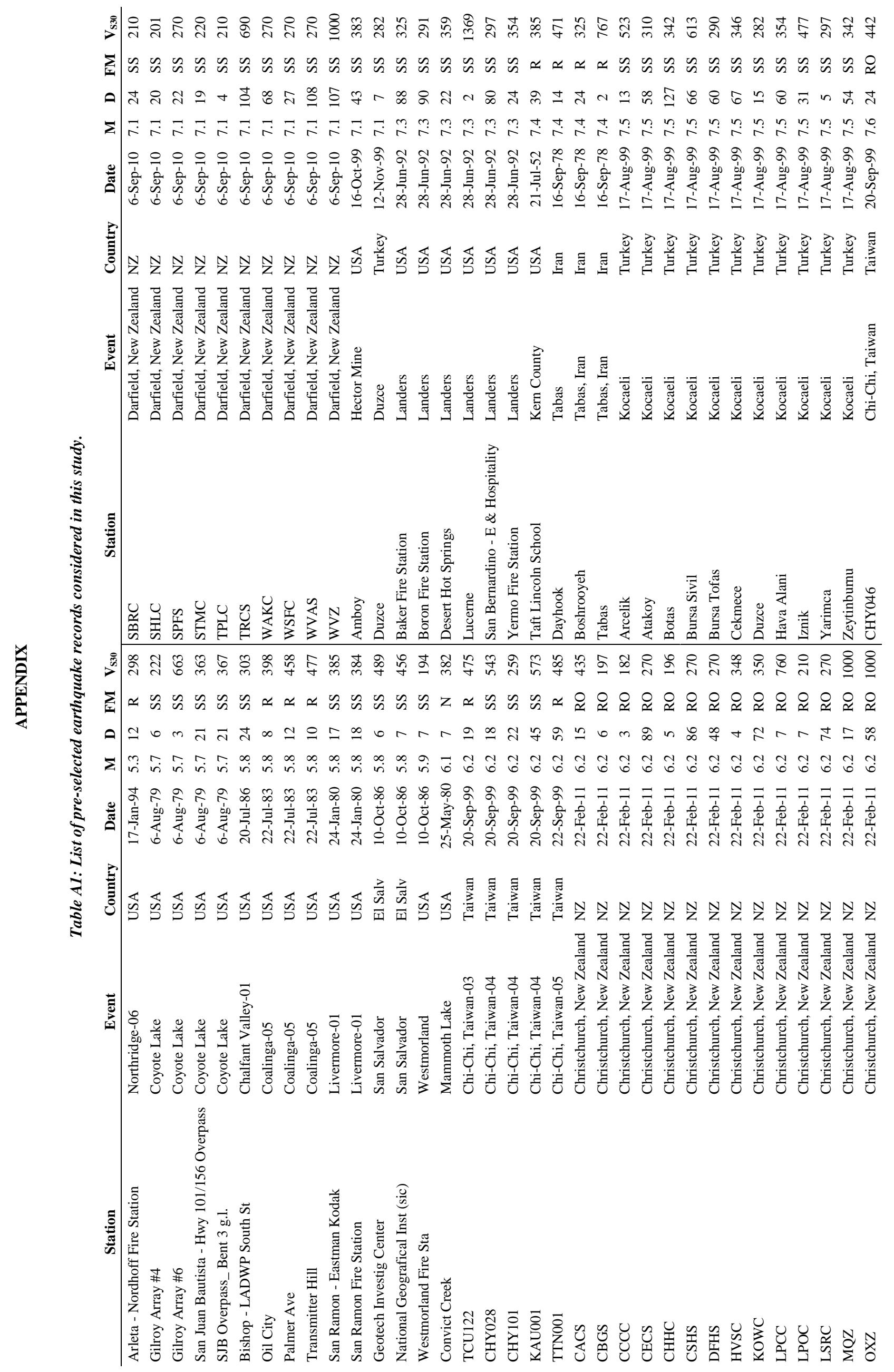




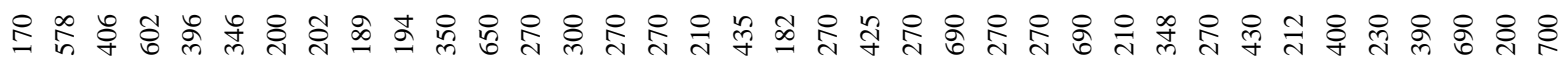

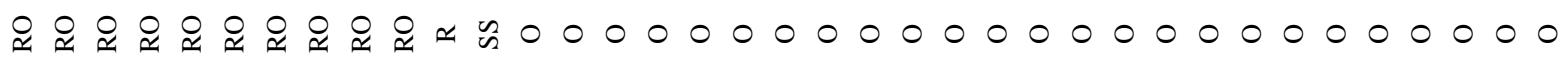

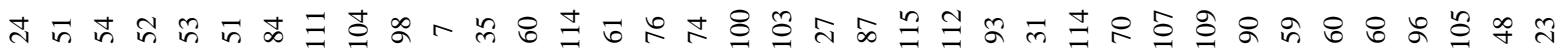
足

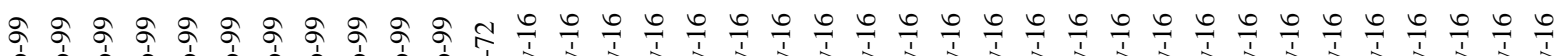

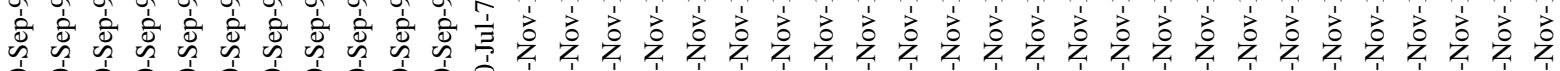
ঠे

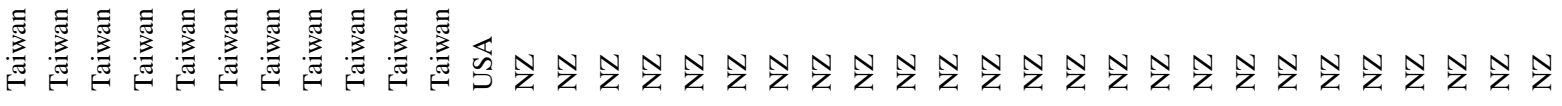

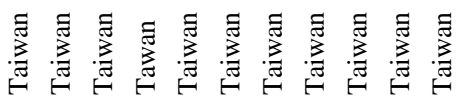

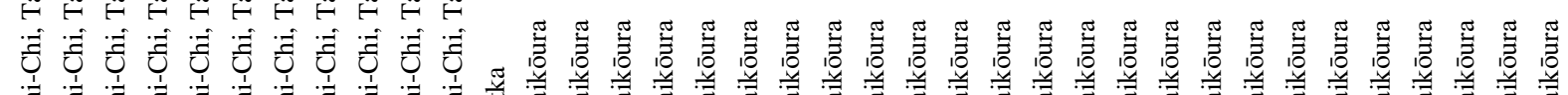

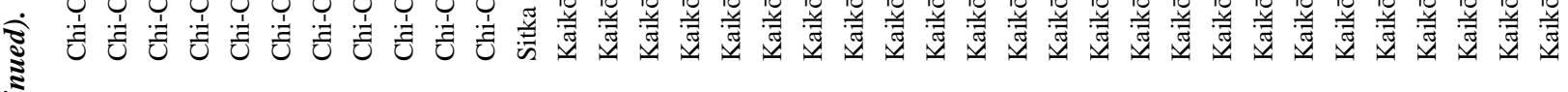

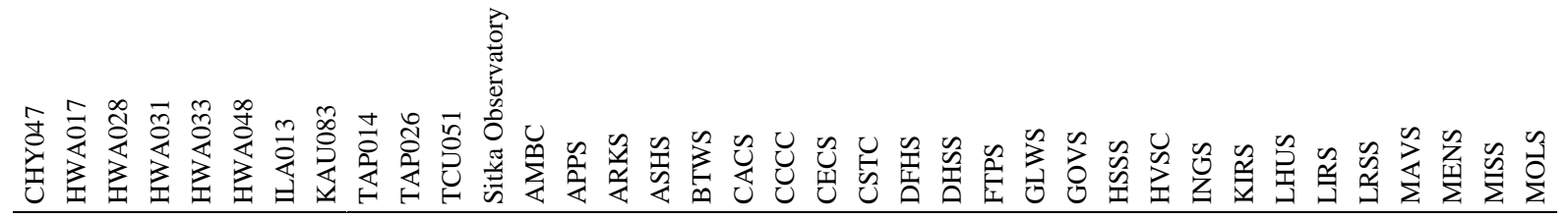

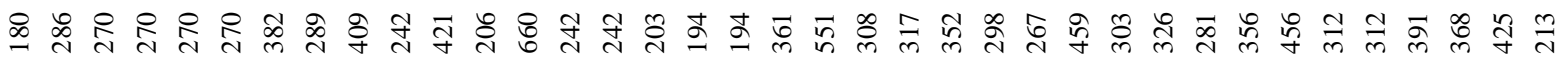

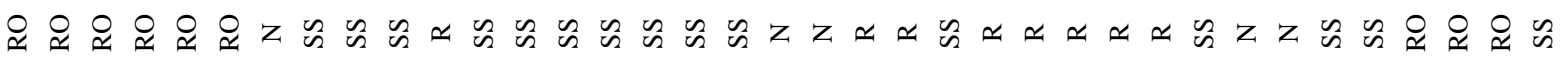

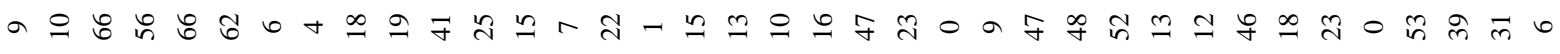

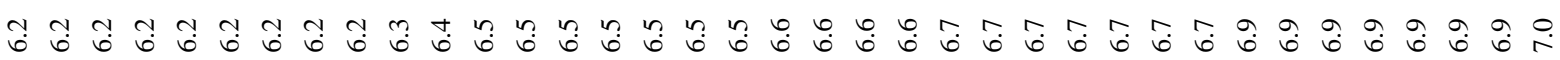

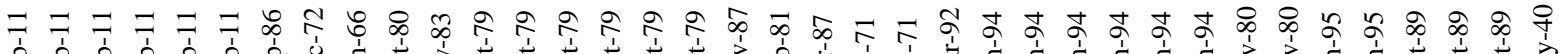

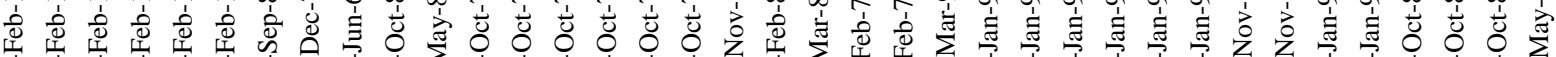

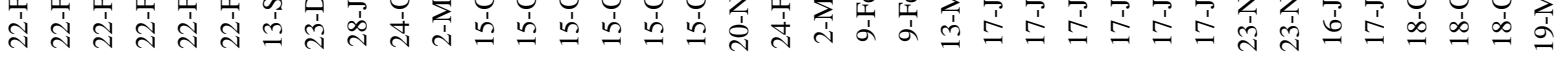

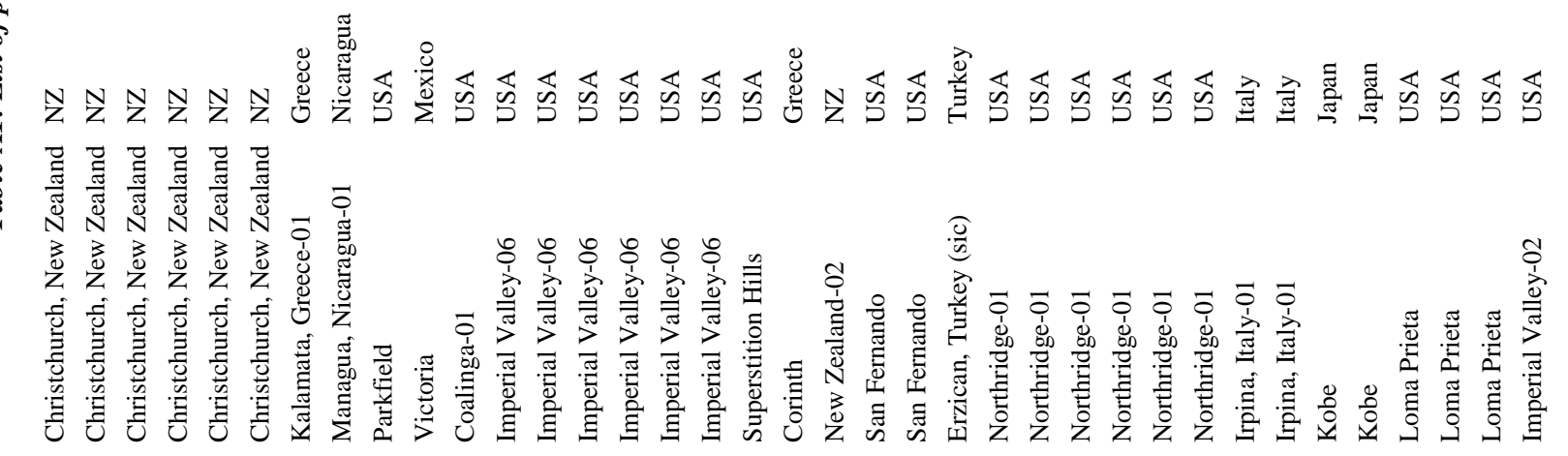

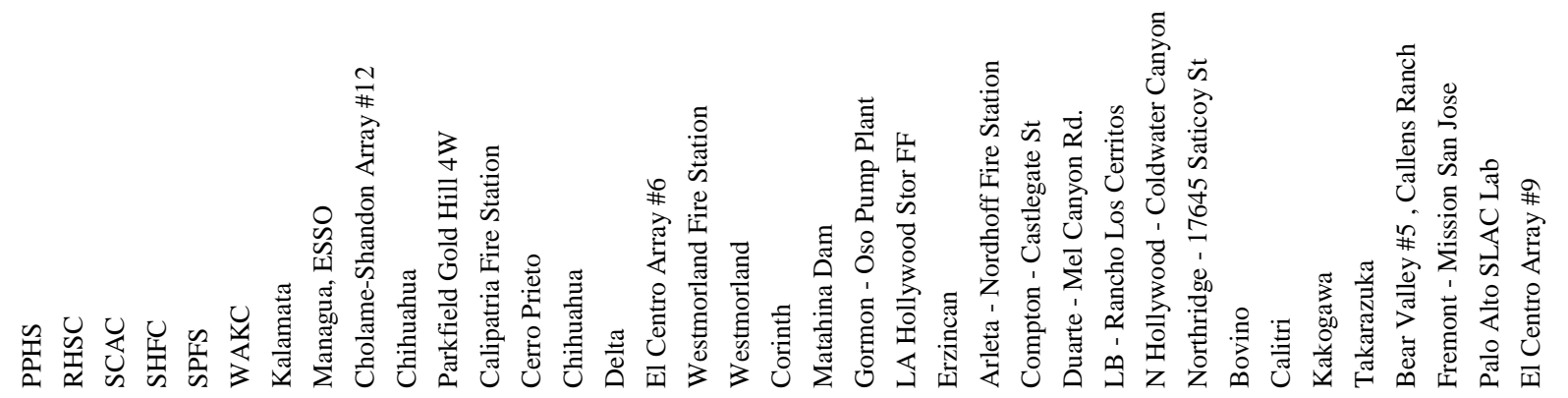




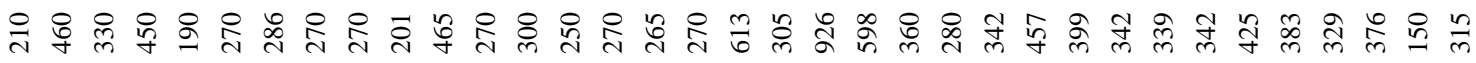

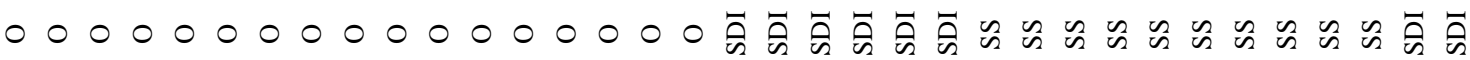

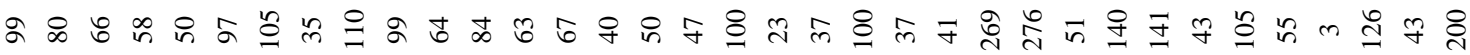

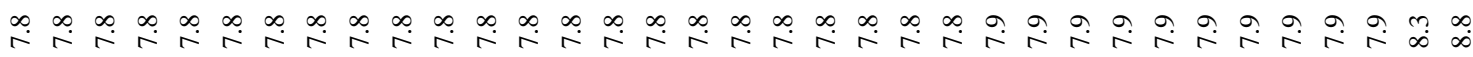

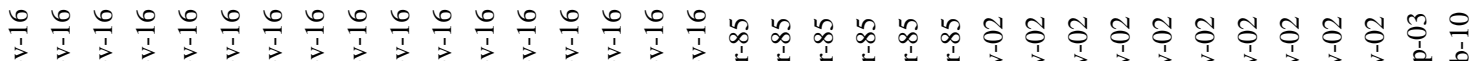

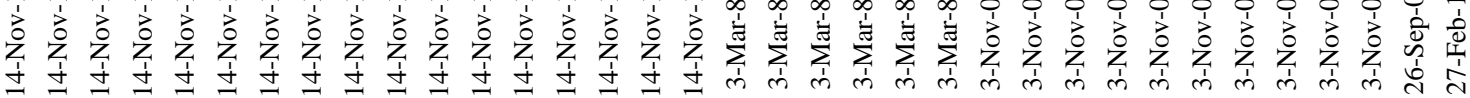

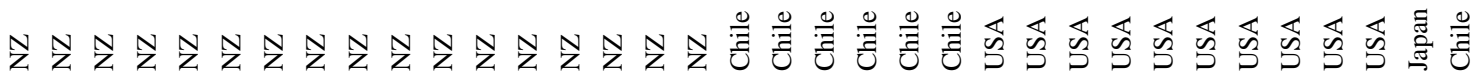

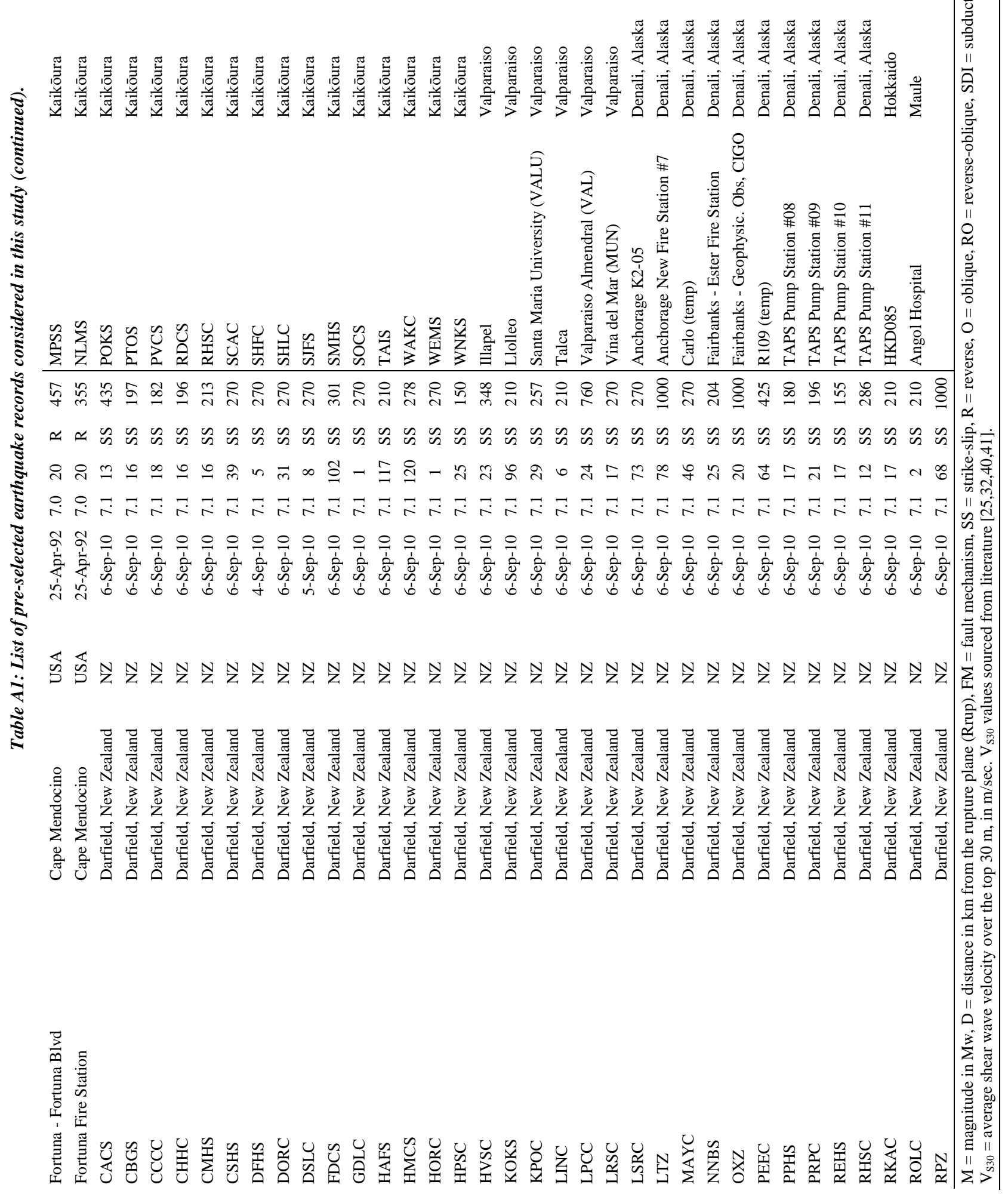




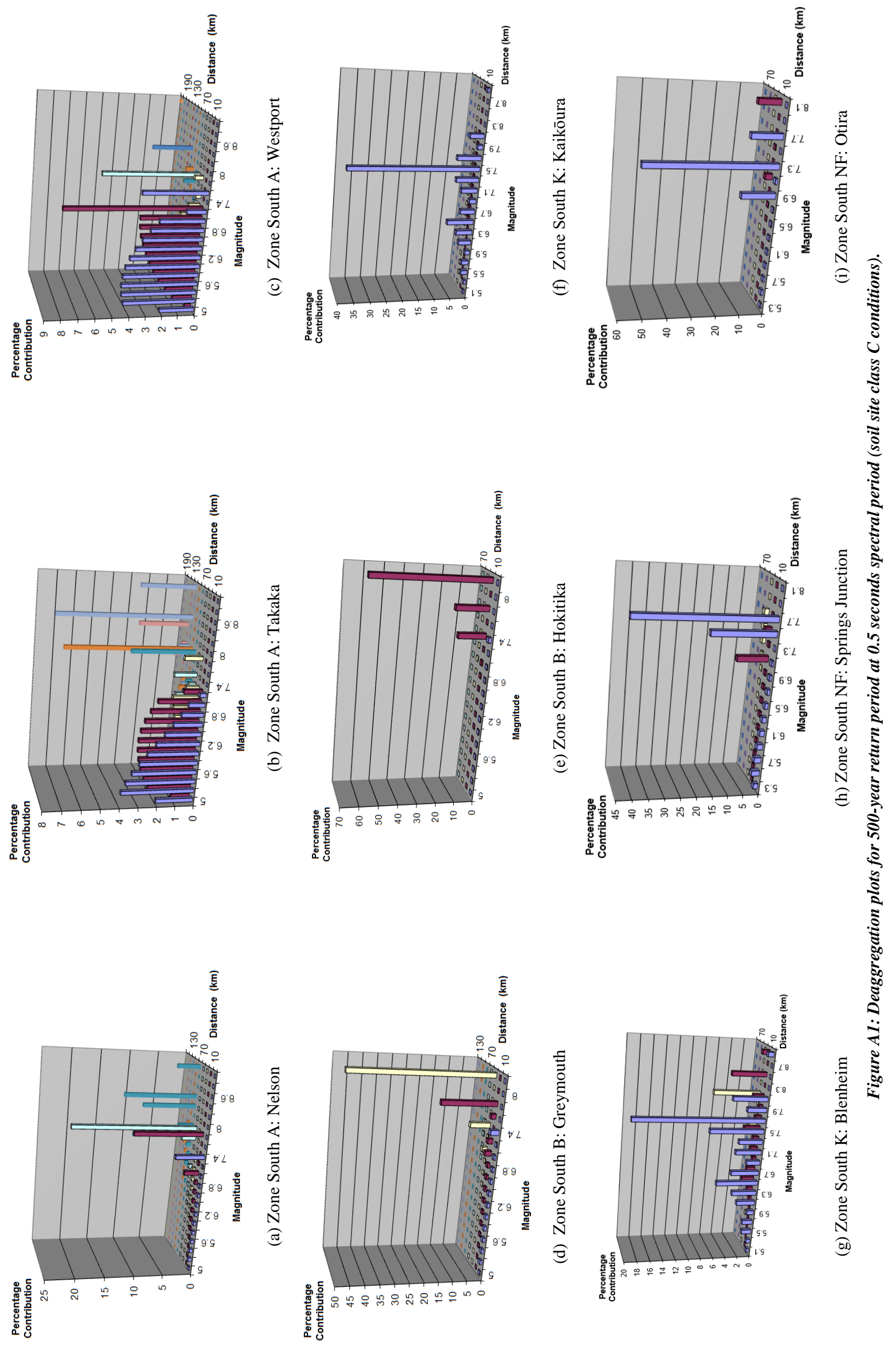



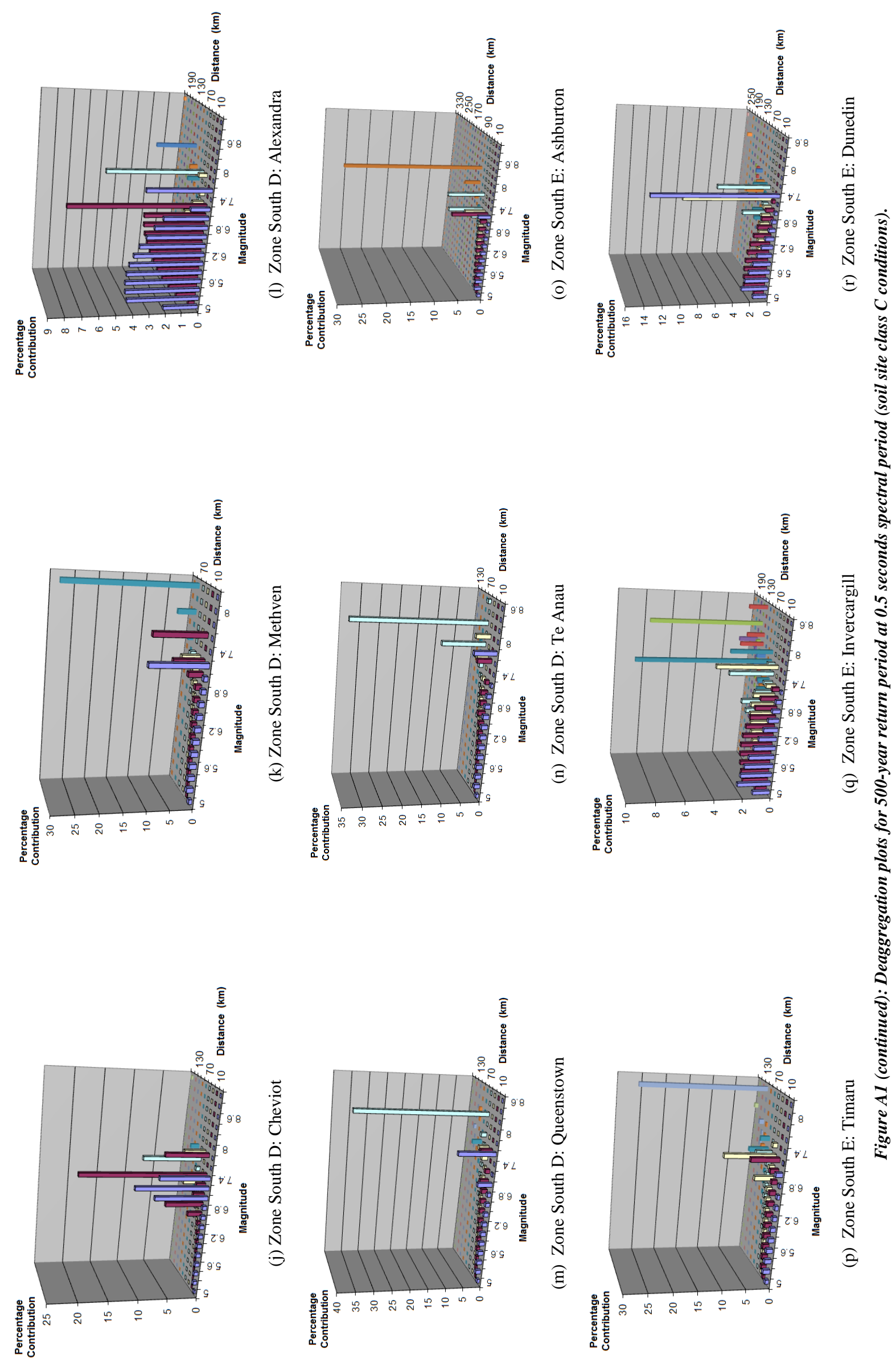